\title{
Expression of the IGF Axis Is Decreased in Local Prostate Cancer but Enhanced after Benign Prostate Epithelial Differentiation and TGF- $\beta$ Treatment
}

\author{
Petra Massoner, ${ }^{*}$ Michael Ladurner Rennau, ${ }^{*}$ \\ Isabel Heidegger, ${ }^{*}$ Anita Kloss-Brandstätter, ${ }^{\dagger}$ \\ Monika Summerer, ${ }^{\dagger}$ Eva Reichhart, ${ }^{*}$ \\ Georg Schäfer, ${ }^{*}$ and Helmut Klocker ${ }^{*}$ \\ From the Division of Experimental Urology, Department of \\ Urology, and Division of Genetic Epidemiology, ${ }^{\dagger}$ Department of \\ Medical Genetics, Molecular and Clinical Pharmacology, \\ Innsbruck Medical University, Innsbruck, Austria
}

The insulin-like growth factor (IGF) axis is a molecular pathway intensively investigated in cancer research. Clinical trials targeting the IGF1 receptor (IGF1R) in different tumors, including prostate cancer, are under way. Although studies on the IGF axis in prostate cancer have already entered into clinical trials, the expression and functional role of the IGF axis in benign prostate and in prostate cancer needs to be better defined. We determined mRNA expression levels of the IGF axis in microdissected tissue specimens of local prostate cancer using quantitative PCR. All members of the IGF axis, including IGF1, IGF2, IGF binding proteins 1 through 6 , and insulin receptor, were measured in both the stromal and epithelial compartments of the prostate. IGF1, IGF2, IGF1R, and insulin receptor were down-regulated in local prostate cancer tissue compared with matched benign tissue, suggesting that the IGF axis is not induced during prostate cancer development. Using a new prostate epithelial differentiation model, we demonstrate that the expression of the IGF axis is enhanced during normal prostate epithelial differentiation and regulated by tumor growth factor (TGF)- $\beta$. Our data reveal a functional role of the IGF axis in prostate differentiation, underscoring the importance of the IGF axis in normal development and emphasizing the importance of accurate target validation before moving to advanced clinical trials. (Am J Pathol 2011, 179: 2905-2919; DOI: 10.1016/j.ajpath.2011.08.026)

Numerous clinical trials targeting the insulin-like growth factor 1 receptor (IGF1R) in different tumors, such as breast cancer, colorectal cancer, leukemia (acute lymphoblastic leukemia and chronic myelogenous leukemia), non-small cell lung cancer (NSCLC), ovarian cancer, pancreatic cancer, prostate cancer, Ewing's sarcomas, and others, are under way ${ }^{1,2}$ (ongoing trials at http://www.clinicaltrials.gov). Encouraging data from phase 2 studies in NSCLC and sarcomas led to rapid development of phase 3 studies. ${ }^{1}$ In December 2009 and March 2010, however, two phase 3 studies of the IGF1Rspecific antibody (figitumumab) in combination with chemotherapy (paclitaxel plus carboplatin) or erlotinib (an epidermal growth factor receptor tyrosine kinase inhibitor) in patients with advanced NSCLC were halted ${ }^{3,4}$ (archive available at http://www.pfizer.com/news/pressreleases/ pfizerpressreleasearchive.jsp; released December 29, 2009, and March 11, 2010; Pfizer Inc, New York, NY). Apart from the lack of efficacy, the studies were discontinued because of safety concerns. Serious adverse effects, such as infection, hemorrhaging and hemoptysis, cardiovascular and cardiopulmonary failure, or unknown causes of death, were more frequently observed in the figitumumab arm compared with the control arm. Other adverse effects attributed to the use of figitumumab were hyperglycemia, dehydration, asthenia, thrombocytopenia, peripheral neuropathy, anemia, fatigue, and pneumonia. ${ }^{5}$ The low efficacy and the serious adverse effects of the anti-IGF1R therapy observed in these phase 3 studies posed the question, "Have we possibly moved too early to clinical trials without entirely understanding the importance of the IGF1R in normal physiologic function?"

Supported by the Comet Center Oncotyrol (project 3.1), the Austrian Cancer Foundation Tyrol, the Österreichische Nationalbank (OENB grant 13059 to A.K.B.), and the Autonomous Province of Bolzano - South Tyrol (grant 37/40.3).

Accepted for publication August 24, 2011.

Supplemental material for this manuscript can be found at $h t t p: / / a j p$. amjpathol.org or at doi: 10.1016/j.ajpath.2011.08.026.

Address reprint requests to Petra Massoner, Ph.D., or Helmut Klocker, Ph.D., Department of Urology, Division of Experimental Urology, Innsbruck Medical University, Anichstr.35, 6020 Innsbruck, Austria. E-mail: Petra.Massoner@i-med.ac.at or Helmut.Klocker@i-med.ac.at. 
IGF1R is a member of a regulatory network of multiple components, named the IGF axis. The IGF axis exerts crucial functions in both normal physiology and pathophysiology. IGF proteins were described to regulate normal and malignant growth, proliferation, survival, tissue homeostasis, differentiation, energy supply, energy consumption, and cellular metabolism. ${ }^{6-8}$ The IGF axis is composed of the ligands IGF1 and IGF2, six different high-affinity IGF-binding proteins (IGFBPs) that exert modulatory functions, IGF1R, IGF2R, and insulin receptor (INSR). The INSR exists in two different isoforms, namely, INSR-A and INSR-B, which have different IGF affinities. The structural similarity of IGF1R and INSR permits the formation of IGF1R/INSR heterodimer receptors formed by subunits of both receptor proteins. ${ }^{9}$ IGF1R/INSR heterodimer receptors are spontaneously formed when the different receptors are expressed, and they are the most abundant receptor subtype in many tissues. Investigating the IGF1R as a single molecule highly underscores the importance of the IGF axis as a molecular network.

The IGF axis is intensely investigated in prostate cancer research. In in vitro studies, IGFs were shown to promote proliferation, migration, and survival of prostate cancer cells. ${ }^{10-13}$ In prostate cancer tissues, IGF expression levels were measured primarily using immunohistochemistry techniques. The results reported were often inconsistent. For example, IGF1R levels were reported to be down-regulated, ${ }^{14}$ up-regulated, ${ }^{15,16}$ or not changed ${ }^{17,18}$ in local prostate cancer. Clinical trials investigating the therapeutic efficacy of an anti- IGF1R therapy in prostate cancer are registered in the US National Institutes of Health database of clinical studies (http://www.clinicaltrials.gov). Most trials examine the benefits of IGF1R inhibition on advanced and therapyresistant prostate cancer (ClinicalTrials identifiers: NCT01026623, NCT00562380, NCT00976508), whereas one trial focuses on local prostate cancer (NCT00769795). In the latter, the anti-IGF1R therapy is investigated as neoadjuvant therapy inhibiting cancer progression. Although studies on the IGF axis in prostate cancer have already reached clinical trials, the functional role of the IGF axis in the benign prostate and in prostate cancer was not fully elucidated to date.

To advance understanding of the IGF axis in prostate cancer, we investigated IGF mRNA expression levels in microdissected local prostate cancer tissues using quantitative real-time PCR. We measured all members of the IGF axis, including IGF1, IGF2, IGFBP1-IGFBP6, IGF1R, IGF2R, and INSR, and showed that several members of the IGF axis are down-regulated in local prostate cancer tissues in both the epithelial and stromal compartments. Using a new prostate epithelial differentiation model, we determined the expression of the IGF axis during normal prostate epithelial differentiation and transforming growth factor (TGF)- $\beta$ treatment. Our data reveal a functional role of the IGF axis in normal prostate differentiation, underscoring the importance of the IGF axis in normal development. These results indicate that the IGF1R is not an ideal molecular target for every cancer entity and every cancer stage (eg, local prostate cancer), therefore emphasizing the importance of careful target validation before moving to advanced clinical trials.

\section{Materials and Methods}

\section{Tissue Samples}

The use of tissue samples from radical prostatectomy specimens with histopathologically confirmed local prostate cancer was approved by the Ethics Commission of the Innsbruck Medical University (study code UN3436), and all patients involved in this study provided their informed consents. Tissue samples from radical prostatectomy specimens were selected from the Innsbruck Prostate Biobank established in association with the Tyrolean PSA screening project for the early detection of prostate cancer. ${ }^{19}$ Three different tissue sample sets were used. Sample set 1, consisting of 20 local prostate cancer specimens assigned according to their Gleason score (GSC) (GSC 5: $n=4$; GSC 6: $n=6$; GSC 9: $n=9$; GSC 10: $n=1$ ), was used for laser capture microdissection (LCM). Tissues of sample set 1 were selected to ensure accurate separation of epithelial and stromal cells by LCM. Four different cell populations were isolated from each tissue: benign epithelial cells, benign epithelial-associated stromal cells, cancer cells, and cancer-associated stromal cells. Sample set 2 (10 local prostate cancer specimens; GSC 6: $n=1$; GSC $8: n=7$; GSC 9: $n=2$ ) was selected to confirm the results of sample set 1 in an independent LCM approach. Two different cell populations, benign epithelial and cancer cells, were isolated from tissues of sample set 2. For immunohistochemical analysis, the samples of sample set 1 were extended by sample set 3 , resulting in a total of 44 local prostate cancer specimens (GSC 5: $n=8$; GSC 6: $n=10$; GSC7: $n=7$; GSC 8: $n=1$; GSC 9: $n=17$; GSC 10: $n=1$ ).

\section{Laser Capture Microdissection}

Frozen tissues were cut into 8- $\mu \mathrm{m}$ sections and mounted on sterile, RNase-free microscope slides (Menzel, Braunschweig, Germany). The slides were stained with H\&E. Histopathologic analysis, tumor grading, and exact definition of tumor localization and extent were performed by a uropathologist (G.S.). Parallel slides were used for LCM and pretreated for 1 minute in each of the following precooled solutions: $75 \%$ ethanol, RNase-free water, $100 \%$ ethanol (twice), and xylene (twice). Afterward the slides were air-dried for 15 minutes. The LCM was performed on a Pix Cell II microdissection microscope (Arcturus, Life Technologies, Carlsbad, CA) using 3000 laser impulses (settings: spot size, $15 \mu \mathrm{m}$; pulse time, 1-3 milliseconds; pulse energy, 60-90 $\mathrm{mW}$ ) to obtain tissue material for one RNA isolation. Total working time for the isolation of cells for one RNA isolation was 30 to 40 minutes. After LCM the tissues were lysed in $50 \mu \mathrm{L}$ of PicoPure extraction buffer (Arcturus) supplemented with 50 ng of Poly-A-RNA carrier (Qiagen, Germantown, MD) and stored at $-80^{\circ} \mathrm{C}$ until 
used for RNA isolation. The different cell populations (benign epithelial, benign epithelial-associated stromal, cancer, and -cancer-associated stromal cells for sample set 1 and benign epithelial and cancer cells for sample set 2) were isolated from one slide of every tissue (representative microdissection in Supplemental Figure S1; available at $h$ ttp://ajp.amjpathol.org). To investigate the stromal-epithelial interaction, benign epithelial-associated stromal and cancer-associated stromal cells were defined as the tissues surrounding directly $(0-10$ cell layers) benign or malignant glands, respectively. Distant stromal cells ( $>10$ cell layers apart from glands) were not used for the analysis. The accurate separation of the tissues by LCM was controlled by a uropathologist (G.S.) and confirmed via expression analysis of tissue specific markers (see Supplemental Figure S2A at http://ajp. amjpathol.org).

\section{Expression Analysis}

RNA from microdissected cells was isolated using the PicoPure RNA isolation kit (Arcturus). cDNA was generated using I-Script reverse transcriptase (Bio-Rad Laboratories, Vienna, Austria) and random primers. cDNA amplification was performed with a PreAmp mastermix kit (Applied Biosystems, Life Technologies, Carlsbad, CA). The manufacturer's instructions were followed for all kits. The PreAmp mastermix kit amplifies defined cDNA targets in a multiplex preamplification PCR, thereby stretching samples containing low cDNA amounts for quantitative PCR. A primer pool containing all primers used for quantitative PCR (Table 1) in a final concentration of 40 $\mathrm{nmol} / \mathrm{L}$ was used to amplify the cDNAs by PreAmp mastermix kit. Fourteen cycles of amplification were applied. Linear cDNA amplification was controlled by comparing quantitative PCR data of amplified cDNA versus nonamplified cDNA (see Supplemental Figure S2B at $h t t p: / /$ ajp.amjpathol.org). Quantitative PCR was performed on ABI 7500 fast and ABI 7900 real-time PCR systems (Applied Biosystems) using Taqman master mix (Applied Biosystems). Primer pairs and fluorescent probes for Taqman real-time PCR were designed according to sequences from the Nucleotide Sequence Database of the National Center for Biotechnology Information using $A B I$ Prism Primer Express Software 2.0.0 (Applied Biosystems) or purchased as predesigned assays on demand (Applied Biosystems). All probes were synthesized spanning an exon-exon boundary and labeled with 5'FAM reporter dye and 3'TAMRA quencher dye. Detailed information on the used Taqman assays, including sequences and PCR efficiencies, is provided in Table 1. Primers and probes were applied in a final concentration of 800 and $150 \mathrm{nmol} / \mathrm{L}$, respectively. All primer-probe pairs were characterized by amplification of a five-step 10fold dilution series of standardized cDNA and by comparing the resulting slopes. The corresponding efficiencies were calculated according to the equation $\mathrm{E}=10^{-\frac{1}{\text { slope }}}$ (Table 1 ). The relative expression ratios of the target genes were determined based on the PCR efficiency (E) of the primer- probe pairs and the $\mathrm{C}_{\mathrm{T}}$ deviation in comparison to a housekeeping gene as follows:

$$
\text { Relative expression ratio }=\frac{E_{\text {target }}{ }^{-C T_{\text {target }}}}{E_{\text {reference }}{ }^{-C T_{\text {reference }}}}
$$

Several housekeeping genes [18S rRNA, $\beta$-actin (ACTB), glyceraldehyde-3-phosphate dehydrogenase $(G A P D H)$, hypoxanthine guanine phosphoribosyl transferase (HPRT1), RPL13A, and TATA-box binding protein $(T B P)]$ were tested before expression analysis. We found HPRT1 and TBP to be the most stably expressed in both prostate tissues and prostate cell lines and selected these genes as endogenous controls (correlation of HPRT1 and TBP in Supplemental Figure S2C at $h t t p: / / a j p . a m j p a t h o l . o r g)$. Controls for precise microdissection, linear cDNA amplification, and accurate housekeeping gene selection were included in the study (see Supplemental Figure S2, A-C, at http:// ajp.amjpathol.org).

\section{Immunohistochemistry}

Tissue microarrays (TMAs) were produced for sample sets 1 and $3(n=44)$. The TMAs contained cancer $(n=$ $3)$ and benign $(n=1)$ cores of prostate tissues from each patient. One core had a diameter of $0.6 \mathrm{~mm}$. The TMAs were cut into $5-\mu \mathrm{m}$ sections. Antigen retrieval and immunohistochemistry were performed using a Discovery XT automated slide-staining system (Ventana Medical Systems, Roche Group, Tucson, AZ). All target antibodies were tested on a test TMA consisting of different human tissue samples. Immunohistochemical stainings were evaluated by a uropathologist (G.S.). Optimal antigen retrieval conditions were established for all target antibodies. Target antibodies, supplier, article number, concentrations, and antigen retrieval conditions used were anti-IGF1R $\beta$ (Santa Cruz Biotechnology, Santa Cruz CA), sc-713, 1:100, cc1 Ventana Discovery standard pretreatment corresponding to 24 minutes of heat pretreatment $\left(98^{\circ} \mathrm{C}\right)$ in Tris/borate/EDTA-based buffer at $\mathrm{pH} 8$; antiIGF1R (R\&D Systems, Minneapolis, MN), mab391, 1:500, cc1 standard pretreatment; anti-INSR $\beta$ (Santa Cruz Biotechnology), sc-711, 1:100, cc1 standard pretreatment; and anti-INSR (Millipore Upstate Biotechnology, Billerica, MA), 07-724, 1:300, cc1 standard pretreatment. Target antibodies were incubated for 1 hour at $37^{\circ} \mathrm{C}$, followed by iView diaminobenzidine (DAB) detection (DAB visualization; Ventana Medical Systems) and hematoxylin counterstaining. Images were acquired using an Axio Imager M1 microscope (Zeiss, Jena, Germany) and TissueFAXS software (TissueGnostics, Vienna, Austria). Antibody specificity was controlled using blocking peptides, alternative target antibodies, and cell culture controls (see Supplemental Figure S3 at http://ajp.amjpathol.org). Quantitative immunohistochemistry analysis was performed using HistoQuest immunohistochemistry analysis software (TissueGnostics), a cell-based staining intensity analysis tool using a nuclear cellular identification marker (in this case hematoxylin), followed by quantitative anal- 
Table 1. Gene Expression Assays Used in This Study

\begin{tabular}{|c|c|c|c|c|c|}
\hline \multirow[b]{2}{*}{ Gene } & \multirow{2}{*}{$\begin{array}{l}\text { Assay } \\
\text { type }^{*}\end{array}$} & \multirow[b]{2}{*}{ Assay no. } & \multicolumn{3}{|c|}{ Sequence } \\
\hline & & & Forward primer & Reverse primer & Taqman probe \\
\hline$A R$ & Own & & 5'-AGGATGCTCTACTTCGCCCC-3' & 5'-ACTGGCTGTACATCCGGGAC-3' & $\begin{array}{l}\text { 5'-TGGTTTTCAATGAGTACCG } \\
\text { CATGCACA-3' }\end{array}$ \\
\hline GAPDH & $A B I$ & 4310884E & & & \\
\hline HPRT1 & Own & & $\begin{array}{l}\text { 5'-GCTTTCCTTGGTCAGGCA } \\
\text { GTA-3' }\end{array}$ & $\begin{array}{l}5^{\prime} \text { - GTCTGGCTTATATCCAACACT } \\
\text { TCGT-3' }\end{array}$ & $\begin{array}{l}5^{\prime} \text {-TCAAGGTCGCAAGCTTGCTG } \\
\text { GTGAAAAGGA-3' }\end{array}$ \\
\hline IGF1 & Own & & 5'-TCAGCTCGCTCTGTCCGTG-3' & $\begin{array}{l}5^{\prime}-\mathrm{TGCACTCCCTCTACTTGC} \\
\text { GTT-3 }\end{array}$ & $\begin{array}{l}5^{\prime}-\text { TGCCCAAGACCCAGAAGGA } \\
\text { AGTACATTTG-3' }\end{array}$ \\
\hline IGF1R & Own & & $\begin{array}{l}5^{\prime}-\text { CCTCCAACTTCGTCTTTG } \\
\text { CAA-3' }\end{array}$ & $\begin{array}{l}5^{\prime}-\text { CAGGTCACTGGCCCA } \\
\text { GGA-3' }\end{array}$ & $\begin{array}{l}5^{\prime}-\text { TGCCCGCAGAAGGAGCA } \\
\text { GATGACA-3' }\end{array}$ \\
\hline IGF2 & Own & & $\begin{array}{l}5^{\prime}-\text { GAGCTCGAGGCGTTC } \\
\text { AGG-3' }\end{array}$ & $\begin{array}{l}5^{\prime} \text { - GTCTTGGGTGGGTAGAGC } \\
\text { AATC-3' }\end{array}$ & $\begin{array}{l}5^{\prime}-\mathrm{AGGCCAAACGTCACCGTC} \\
\text { CCC-3' }\end{array}$ \\
\hline IGF2R & Own & & $\begin{array}{l}5^{\prime}-\text { CAACTTGTCCAGCCTTTC } \\
\text { CAC- } 3^{\prime}\end{array}$ & $\begin{array}{l}5^{\prime}-\text { ACCCCAACGCTGTAG } \\
\text { GTG-3' }\end{array}$ & $\begin{array}{l}\text { 5'-AGCACCTTTAAGGTGACTC } \\
\text { GCGACTCG-3' }\end{array}$ \\
\hline IGFBP1 & Own & & $\begin{array}{l}5^{\prime}-\text { GGCTCTCCATGTCACCA } \\
\text { ACA-3' }\end{array}$ & $\begin{array}{l}5^{\prime}-\text { TCCTGTGCCTTGGCTAAA } \\
\text { CTC- } 3^{\prime}\end{array}$ & $\begin{array}{l}5^{\prime}-\text { AAATGGAAGGAGCCCTGCC } \\
\text { GAATAGAAC- } 3^{\prime}\end{array}$ \\
\hline IGFBP2 & Own & & $\begin{array}{l}5^{\prime}-\text { CCAACTGTGACAAGCAT } \\
\text { GGC-3' }\end{array}$ & $\begin{array}{l}5^{\prime}-\text { TCACACACCAGCACTC } \\
\text { CCC-3' }\end{array}$ & $\begin{array}{c}5^{\prime} \text {-GTACAACCTCAAACAGTGC } \\
\text { AAGATGTCTCTGAA-3' }\end{array}$ \\
\hline IGFBP3 & Own & & $\begin{array}{l}5^{\prime}-\text { AGCACAGATACCCAGAACTTC } \\
\text { TCC-3' }\end{array}$ & $\begin{array}{l}5^{\prime} \text { - CATTTCTCTACGGCAGGG } \\
\text { ACC }-3^{\prime}\end{array}$ & $\begin{array}{l}5^{\prime} \text {-CCGAGTCCAAGCGGGAGA } \\
\text { CAGAATATG- } 3^{\prime}\end{array}$ \\
\hline IGFBP4 & Own & & $\begin{array}{l}5^{\prime}-\text { AGGCCATCCAGGAAAG } \\
\text { CCT-3' }\end{array}$ & $\begin{array}{l}5^{\prime}-\text { TCGAATTTTGGCGAAGT } \\
\text { GCT-3' }\end{array}$ & $\begin{array}{l}5^{\prime}-\text { CCTCTGACAAGGACGAG } \\
\text { GGTGACCA-3' }\end{array}$ \\
\hline IGFBP5 & Own & & $\begin{array}{l}5^{\prime}-\text { GAAAGCAGTGCAAACCTT } \\
\text { CCC- } 3^{\prime}\end{array}$ & $\begin{array}{l}5^{\prime}-\mathrm{CTTGTCCACGCACCA} \\
\text { GCA-3' }\end{array}$ & $5^{\prime}-$ TGCCACGCTTGCGGCCA-3' \\
\hline IGFBP6 & Own & & $\begin{array}{l}\text { 5'-AGGAATCCAGGCACCTCT } \\
\text { ACC- } 3^{\prime}\end{array}$ & $\begin{array}{l}5^{\prime}-\text { TGCAGCACTGAGTCCAGA } \\
\text { TGT-3' }\end{array}$ & $\begin{array}{l}\text { 5'-CAAGACACTGAGATGGGCC } \\
\text { CATGCCGT-3' }\end{array}$ \\
\hline INSR & Own & & $\begin{array}{l}5^{\prime} \text { - CAAGTGCATCCCTGAGTG } \\
\text { TCC }-3^{\prime}\end{array}$ & $\begin{array}{l}5^{\prime}-\text { CGAGTCGATGGTCTTCT } \\
\text { CGC-3' }\end{array}$ & $\begin{array}{l}5^{\prime} \text {-GATGAATTCCAGCAACTTG } \\
\text { CTGTGCACC- } 3^{\prime}\end{array}$ \\
\hline INSRA & Own & & $\begin{array}{l}\text { 5'-TGGTTTTCGTCCCCAG } \\
\text { GCC- } 3^{\prime}\end{array}$ & $\begin{array}{l}5^{\prime}-\text { CCACCGTCACATTCCC } \\
\text { AAC- } 3^{\prime}\end{array}$ & $\begin{array}{l}5^{\prime}-\text { TCTCGGAAACGCAGGTCCC } \\
\text { TTGGCGA-3' }\end{array}$ \\
\hline INSRB & Own & & $\begin{array}{l}5^{\prime} \text {-GTGCCGAGGACCCTAG } \\
\text { GCC-3' }\end{array}$ & $\begin{array}{l}5^{\prime}-\mathrm{CCACCGTCACATTCCC} \\
\text { AAC- } 3^{\prime}\end{array}$ & $\begin{array}{l}5^{\prime}-\text { TCTCGGAAACGCAGGTCC } \\
\text { CTTGGCGA-3' }\end{array}$ \\
\hline $\begin{array}{l}\text { KRT18 } \\
\text { p63 }\end{array}$ & $\begin{array}{l}A B I \\
A B I \\
A B I\end{array}$ & $\begin{array}{l}\mathrm{Hs} 01920599 \\
\mathrm{Hs} 00978338 \\
\mathrm{Hs} 0199489\end{array}$ & & & \\
\hline $\begin{array}{l}\text { SMIH } \\
\text { TBP }\end{array}$ & $\begin{array}{l}\mathrm{ABI} \\
\text { Own }\end{array}$ & & $\begin{array}{l}5^{\prime}-\text { CACGAACCACGGCACTG } \\
\text { ATT-3' }\end{array}$ & $\begin{array}{l}5^{\prime} \text {-TTTTCTTGCTGCCAGTCT } \\
\text { GGAC-3' }\end{array}$ & $\begin{array}{l}5^{\prime}-\text { TCTTCACTCTTGGCTCCT } \\
\text { GTGCACA-3' }\end{array}$ \\
\hline TGFB1 & $A B I$ & Hs00171257 & & & \\
\hline TGFB2 & $A B \mid$ & Hs00234244 & & & \\
\hline TGFB3 & $A B \mid$ & Hs00234245 & & & \\
\hline TGFBR1 & $\mathrm{ABI}$ & Hs00610320 & & & \\
\hline TGFBR2 & $\mathrm{ABI}$ & $\mathrm{Hs} 00234253$ & & & \\
\hline TGFBR3 & $\mathrm{ABI}$ & $\mathrm{Hs} 01114253$ & & & \\
\hline
\end{tabular}

(table continues)

*Own, designed by our study group; $\mathrm{ABI}$, predesigned assay purchased from Applied Biosystems (Life Technologies).

${ }^{\dagger}$ Data represent mean \pm SD of three independent measurements.

ysis of a given marker labeled in a different color (in this case cytoplasmic staining with DAB, brown). For details see Supplemental Figure S4 (available at http://ajp.amjpathol.org) and previous quantification examples. ${ }^{20-22}$ The whole area of each TMA core $\left(0.3 \pm 0.1 \mathrm{~mm}^{2}\right)$ was used for quantification. Mean staining intensities of the investigated proteins in all epithelial cells of the cancer cores (three cores per case; $1800 \pm 500$ cells per core) and the benign cores (one core per case, $1200 \pm 500$ cells per core) were calculated and compared. The analysis was performed for 39 cases; the remaining five cases were excluded due to poor staining quality.

\section{Cell Culture and Treatments}

Primary epithelial cell cultures were established from normal prostate tissue obtained from patients undergoing radical prostatectomy for prostate cancer as previously described. ${ }^{23}$ EP156T and RWPE-1 were used as immortalized models for benign prostate epithelial cells. They are immortalized derivatives from two independent primary cell cultures of benign prostate epithelial cells. ${ }^{24,25}$ EP156T cells were immortalized by hTERT overexpression, express basal cell markers, and resemble a basal cell type, ${ }^{24}$ whereas RWPE-1 cells were immortalized using human papillomavirus 18, express both luminal and basal cell markers, and resemble an intermediate cell type. ${ }^{25}$ EP156T and RWPE-1 were cultured in MCDB 153 medium and K-SFM medium with supplements as previously described. ${ }^{24,25}$ RWPE-2 are v-Ki-ras transformed derivatives of RWPE-1 and were cultured in KSFM medium with supplements as previously described. ${ }^{25}$ Du145, LNCaP, PC3, and VCaP are prostate cancer cell lines. Du145 and PC3 were grown in RPMI 
Table 1. Continued

\begin{tabular}{|c|c|c|c|}
\hline \multicolumn{4}{|c|}{ Standard curve properties ${ }^{\dagger}$} \\
\hline Slope & $R^{2}$ & PCR efficiency & PCR efficiency, \% \\
\hline$-3.44 \pm 0.07$ & $0.99 \pm 0.01$ & $1.95 \pm 0.03$ & $95.3 \pm 2.5$ \\
\hline $\begin{array}{l}-3.63 \pm 0.07 \\
-3.47 \pm 0.18\end{array}$ & $\begin{array}{l}0.99 \pm 0.01 \\
0.99 \pm 0.01\end{array}$ & $\begin{array}{l}1.89 \pm 0.02 \\
1.94 \pm 0.05\end{array}$ & $\begin{array}{l}88.6 \pm 2.3 \\
94.1 \pm 5.4\end{array}$ \\
\hline$-3.44 \pm 0.43$ & $0.92 \pm 0.06$ & $1.96 \pm 0.04$ & $95.5 \pm 3.9$ \\
\hline$-3.53 \pm 0.14$ & $0.99 \pm 0.01$ & $1.92 \pm 0.05$ & $92.1 \pm 4.9$ \\
\hline$-3.46 \pm 0.10$ & $0.99 \pm 0.01$ & $1.95 \pm 0.04$ & $94.5 \pm 3.7$ \\
\hline$-3.51 \pm 0.08$ & $0.99 \pm 0.01$ & $1.93 \pm 0.03$ & $92.5 \pm 2.7$ \\
\hline$-3.55 \pm 0.50$ & $0.98 \pm 0.01$ & $1.91 \pm 0.42$ & $91.0 \pm 3.8$ \\
\hline$-3.40 \pm 0.06$ & $0.99 \pm 0.01$ & $1.97 \pm 0.02$ & $96.7 \pm 2.3$ \\
\hline$-3.48 \pm 0.13$ & $0.99 \pm 0.01$ & $1.94 \pm 0.05$ & $93.8 \pm 4.7$ \\
\hline$-3.50 \pm 0.16$ & $0.99 \pm 0.01$ & $1.93 \pm 0.06$ & $93.2 \pm 5.7$ \\
\hline$-3.51 \pm 0.10$ & $0.99 \pm 0.01$ & $1.93 \pm 0.04$ & $92.6 \pm 3.7$ \\
\hline$-3.47 \pm 0.14$ & $0.98 \pm 0.01$ & $1.94 \pm 0.05$ & $94.2 \pm 4.9$ \\
\hline$-3.38 \pm 0.03$ & $0.93 \pm 0.11$ & $1.98 \pm 0.01$ & $97.6 \pm 1.1$ \\
\hline$-3.57 \pm 0.19$ & $0.98 \pm 0.01$ & $1.91 \pm 0.07$ & $90.6 \pm 6.7$ \\
\hline$-3.58 \pm 0.16$ & $0.96 \pm 0.04$ & $1.90 \pm 0.05$ & $90.3 \pm 5.3$ \\
\hline $\begin{array}{l}-3.48 \pm 0.08 \\
-3.77 \pm 0.13 \\
-3.37 \pm 0.10 \\
-3.48 \pm 0.23\end{array}$ & $\begin{array}{l}0.99 \pm 0.01 \\
0.99 \pm 0.01 \\
0.99 \pm 0.01 \\
0.98 \pm 0.01\end{array}$ & $\begin{array}{l}1.94 \pm 0.03 \\
1.84 \pm 0.04 \\
1.98 \pm 0.02 \\
1.94 \pm 0.06\end{array}$ & $\begin{array}{l}93.7 \pm 2.9 \\
84.1 \pm 3.8 \\
98.1 \pm 1.9 \\
93.9 \pm 5.8\end{array}$ \\
\hline $\begin{array}{l}-3.36 \pm 0.02 \\
-3.72 \pm 0.12 \\
-3.34 \pm 0.10 \\
-3.34 \pm 0.02 \\
-3.53 \pm 0.08 \\
-3.46 \pm 0.10\end{array}$ & $\begin{array}{l}0.99 \pm 0.01 \\
0.99 \pm 0.01 \\
0.98 \pm 0.03 \\
0.98 \pm 0.02 \\
0.97 \pm 0.04 \\
0.98 \pm 0.01\end{array}$ & $\begin{array}{l}1.98 \pm 0.01 \\
1.86 \pm 0.04 \\
1.99 \pm 0.01 \\
1.99 \pm 0.01 \\
1.92 \pm 0.05 \\
1.94 \pm 0.03\end{array}$ & $\begin{array}{l}98.3 \pm 0.9 \\
85.6 \pm 3.5 \\
99.2 \pm 1.3 \\
99.7 \pm 1.2 \\
91.9 \pm 5.2 \\
94.5 \pm 2.8\end{array}$ \\
\hline
\end{tabular}

1640 in the presence of $10 \%$ fetal calf serum, $2 \mathrm{mmol} / \mathrm{L}$ Glutamax, and antibiotics; LNCaP in RPMI 1640 in the presence of $10 \%$ fetal calf serum, $2 \mathrm{mmol} / \mathrm{L}$ Glutamax, $4.5 \mathrm{~g} / \mathrm{L}$ D-glucose, $1 \%$ Na-Pyruvat, and antibiotics; and $\mathrm{VCaP}$ in DMEM in the presence of $10 \%$ fetal calf serum, $2 \mathrm{mmol} / \mathrm{L}$ Glutamax, $6 \mathrm{~g} / \mathrm{L}$ of D-glucose, and antibiotics (all materials from PAA Laboratories, Pasching, Austria). The identity of the used cancer cell lines was confirmed by forensic DNA fingerprinting methods using the AmpFISTR SGM Plus PCR amplification kit (Applied Biosystems).

For differentiation experiments, EP156T and RWPE-1 were exposed to RPMI 1640 containing 10\% fetal calf serum for 6 days (EP156T) or 4 days (RWPE-1; at this time the cells reached confluence), respectively. For TGF- $\beta$ treatment, DU145, EP156T, LNCaP, PC3, RWPE -1 , and VCaP were treated with $3 \mathrm{ng} / \mathrm{mL}$ of TGF- $\beta$
(Sigma-Aldrich, Vienna, Austria) in growth factor-reduced medium (growth medium mixed with empty medium in a ratio of 1:5). After 24 hours the treatment was repeated and 24 hours later the cells were harvested, resulting in a total TGF- $\beta$ exposure time of 48 hours.

\section{Immunofluorescent Staining}

Cells were cultured on microscope cover slides, washed in PBS, and fixed for 15 minutes in $4 \%$ paraformaldehyde in PBS followed by an additional fixation in $-20^{\circ} \mathrm{C}$ cold methanol for 5 minutes. Cellular permeabilization was achieved by exposure to $0.2 \%$ Triton X-100 solved in PBS containing $1 \%$ bovine serum albumin (1\% BSA/PBS) for 5 minutes on ice. Blocking was performed for 30 minutes at room temperature in $1 \%$ BSA/PBS. Primary antibodies 
were incubated in $1 \%$ BSA/PBS for 1 hour at $37^{\circ} \mathrm{C}$. Primary antibodies, supplier, article number, and concentrations used were anti-cytokeratin 8 and anti-cytokeratin 18 (GenAway Biotech, San Diego, CA); 15-288-22753 and 15-288-22752, 1:100; and anti-p63 (Thermo Fisher Scientific Neomarkers, Fremont, CA) and MS-1084-P1, 1:50. Secondary Alexa-Fluor 488- and Alexa-Fluor 555-conjugated donkey or goat anti-chicken and mouse antibodies (Invitrogen, Paisley, UK) were incubated in $1 \%$ BSA/PBS in a dilution of $1: 400$ for 45 minutes at $37^{\circ} \mathrm{C}$. Washing steps were performed in PBS between the single steps of the protocol. Samples were covered with Vectashield mounting medium containing DAPI (Vector Laboratories, Peterborough, UK) and analyzed using an Axio Imager M1 microscope (Zeiss).

\section{Western Blotting}

Cell pellets were lysed in RIPA buffer containing $1 \%$ Triton X-100, protease, and phosphatase inhibitors (Invitrogen). Protein quantification was performed according to the Bradford method. A total of $50 \mu \mathrm{g}$ of protein per lane was supplemented with loading buffer (NuPage; Invitrogen), separated using a $4 \%$ to $12 \%$ Bis-Tris gel (Invitrogen) and transferred onto a nitrocellulose membrane (Invitrogen). The membrane was blocked for 1 hour using starting block buffer (Pierce Biotechnology, Rockford, IL) and incubated at $4^{\circ} \mathrm{C}$ overnight together with the target antibodies. Target antibodies, supplier, article number, and concentrations used were anti-cytokeratin 8 and 18 (Abcam, Cambridge UK), ab15224-1, 1:350; anti-GAPDH, (Millipore Chemicon), mab374, 1:4000; anti-IGF1R (Santa Cruz Biotechnology), sc-713, 1:500; anti-IGFBP3 (Beckman Coulter DSL, Brea, CA), R00535, 1:500; and anti-INSR (Millipore Upstate Biotechnology), 07-724, 1:500. Membranes were washed in Trisbuffered saline for 20 minutes, followed by incubation with fluorescence-labeled secondary antibodies for 1 hour at room temperature (Molecular Probes, Invitrogen, Paisley, UK). The membranes were scanned and analyzed using Odyssey infrared imaging system and Odyssey application software (LiCor Biosciences, Lincoln, NE).

\section{Statistical Analyses}

Statistical calculations were performed using SPSS statistical software, version 18, for Windows (SPSS Inc, Chicago, IL). The Kolmogorov-Smirnov test was used to investigate normal distribution of data sets. Data that were nonnormally distributed were analyzed using Spearman's $\rho$ test for correlation calculations and MannWhitney U-test to analyze the significance of differences between groups. Differences between data following a gaussian (normal) distribution were assessed using Student's t-test. $P<0.05$ was considered significant and displayed as exact values when $P>0.001$. Error bars in the histograms represent SD.

\section{Results}

Down-Regulation of IGF1, IGF2, IGF1R, and INSR mRNA in Local Prostate Cancer Tissue

We analyzed the expression of all members of the IGF axis, including IGF1, IGF2, IGF1R, IGF2R, INSR, and IGFBP1-6, in microdissected prostate tissue using quantitative PCR. We used two independent sample sets isolated in different LCM approaches and normalized to different housekeeping genes to avoid methodologic bias. Apart from the receptors, the members of the IGF axis are secretory proteins and act in an autocrine and paracrine manner; therefore, stromal samples were also included in our analysis (only for sample set 1).

IGF1 and IGF2 were found to be expressed by both epithelial and stromal cells of the prostate. IGF1 and IGF2 expression was down-regulated in prostate cancer areas in cancer cells and cancer-associated stromal cells compared with benign epithelial cells and benign epithelialassociated stromal cells, respectively, indicating that local production of IGF1 and IGF2 is decreased in local prostate cancer areas compared with benign prostate areas (Figure 1A, exact-fold changes and $P$ values in Supplemental Table S1 and Supplemental Table S2 at http://ajp.amjpathol.org). The expression of IGF1 was decreased in high-grade (GSC 8-10) compared with lowgrade (GSC 5-6) cancer and cancer-associated stromal cells (Figure 1C, see Supplemental Table S3 and Supplemental Table $\mathbf{S} 4$ at $h$ ttp://ajp.amjpathol.org). The same tendency was observed for IGF2 (see Supplemental Figure S5A, Supplemental Table S3, and Supplemental Table S4 at http://ajp.amjpathol.org).

IGF1 and IGF2 bind and activate the tyrosine kinase receptors IGF1R and INSR and bind to the decoy receptor IGF2R. We found IGF1R and the two isoforms of the INSR, INSR-A and INSR-B, down-regulated in cancer cells compared with benign epithelial cells, whereas the expression level of the IGF2R was unchanged (Figure 1B, see Supplemental Table S1 at $h$ ttp://ajp.amjpathol.org). Collectively, these data reveal that IGF1, IGF2, IGF1R, and INSR mRNA expression is down-regulated in local prostate cancer areas compared with benign prostate areas.

The IGF growth factors are stabilized in the extracellular space by six different IGFBPs (IGFBP1-6). IGFBP1 mRNA was not detectable in prostate tissue; hence, IGFBP1 was excluded from all further analyses. IGFBP2 through IGFBP6 were expressed by both the epithelial and the stromal compartments of the prostate. Several IGFBPs, notably IGFBP4 and IGFBP6, were expressed more highly in stromal areas than in epithelial areas (see Supplemental Figure S5B and Supplemental Table S5 at http://ajp.amjpathol.org). There were no differences in IGFBP expression in cancer-associated stromal cells compared with benign epithelial-associated stromal cells. IGFBP3, IGFBP4, and IGFBP5 were found to be down-regulated in cancer cells compared with benign epithelial cells in sample set 1 , but this observation was not confirmed in sample set 2 (see Supplemental Figure 

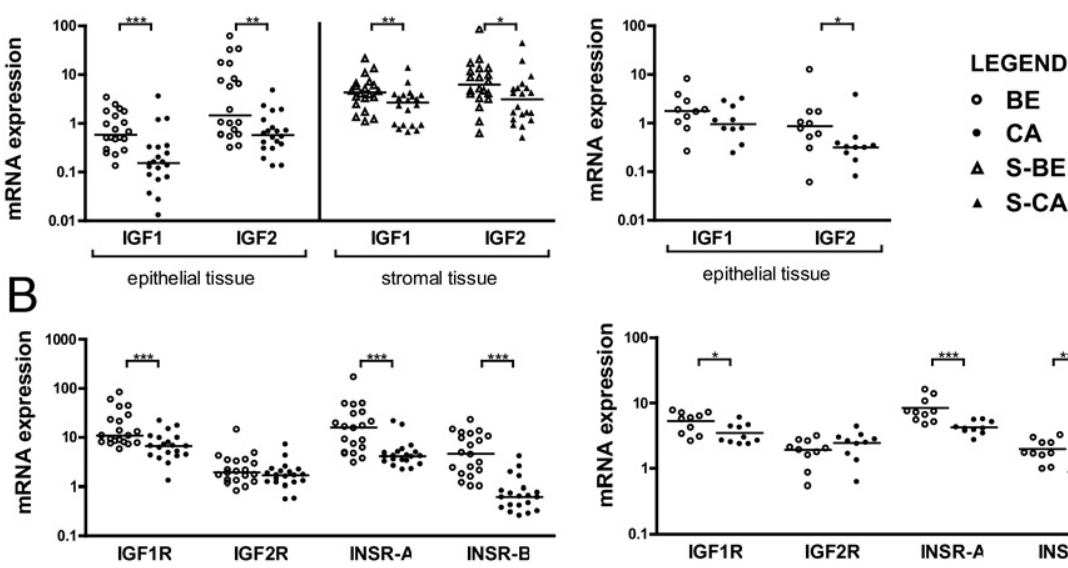

- BE

- CA

$\triangle$ S-BE

S S-CA

epithelial tissue

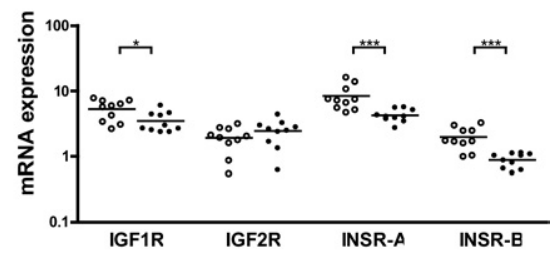

D

sample set 1; $n=20$; HKG, HPRT1
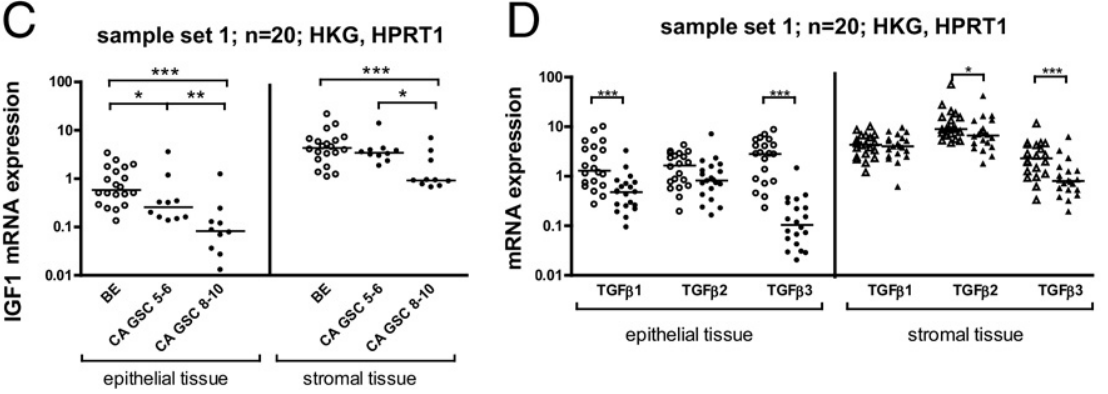

Figure 1. Expression analysis on microdissected prostate tissue reveals that mRNA levels of IGF1, IGF2, IGF1R, INSR-A, and INSR-B are down-regulated in prostate cancer. A: The expression of the growth factors IGF1 and IGF2 is down-regulated in cancer cells (CA) and cancerassociated stroma cells (S-CA) compared with benign epithelial cells (BE) and benign stroma cells (S-BE), respectively. B: The expression of IGF1R, INSR-A, and INSR-B is down-regulated in $\mathrm{CA}$ compared with $\mathrm{BE}$, whereas expression of IGF2R is not changed. C: The expression of IGF1 is reduced in high GSC score (GSC 8-10) compared with low GSC score (GSC 5-6) CA and S-CA. D: The expression of TGF $\beta 1$, TGF $\beta 2$, and TGF $\beta 3$ is down-regulated in CA and S-CA compared with BE and S-BE, respectively. mRNA expression levels were determined by quantitative PCR in microdissected prostate tissues using two independent sample sets normalized to two different endogenous controls (housekeeping genes, $H K G)$. Line, median. Mann-Whitney $U^{-}$ test; ${ }^{*} P<0.05 ;{ }^{* * *} P<0.01 ;{ }^{* * * * *} P<0.001$. The $y$ axis is scaled logarithmically.
S5C and Supplemental Table S1 at http://ajp.amjpathol. org). Overall, we did not detect any change in IGFBP mRNA expression levels in prostate cancer tissue areas compared with benign prostate tissue areas.

A strong correlation among the expression of the different IGF factors was striking in the tissue expression analysis (see Supplemental Table S6 at http://ajp. amjpathol.org). Tissue areas expressing high amounts of one IGF factor (eg, IGF2) also express high amounts of other IGF factors (eg, INSR, IGF2R, IGFBP2, IGFBP3, IGFBP4, IGFBP5, and IGFBP6), confirming that the IGF axis is a tightly controlled molecular network.

Taking all results into account, our expression analysis on microdissected prostate tissues revealed that i) all members of the IGF axis except IGFBP1 are expressed in the prostate by both the epithelial and stromal compartments; ii) mRNA levels of IGF proteins correlate with each other, showing that the IGF axis is a tightly regulated molecular network; and iii) mRNA levels of IGF1, IGF2, IGF1R, and INSR are down-regulated in local prostate cancer tissue areas compared with benign prostate tissue areas.

\section{IGF1R Protein Levels Differ from mRNA Expression Levels in Prostate Tissue}

Several attempts have been made in the last two decades to quantify IGF1R protein levels in prostate tissues using immunohistochemistry. The results reported to date are inconsistent. When we analyzed IGF1R protein levels in prostate tissues using immunohistochemistry, a pre- dominant epithelial localization of IGF1R was observed (Figure 2A). Quantification of IGF1R protein levels revealed comparable IGF1R levels in local prostate cancer areas and benign prostate areas (Figure 2B). Antibody specificity was confirmed using blocking peptides, several cell culture controls, and a second anti-IGF1R antibody from an independent supplier (see Supplemental Figure S3 at http://ajp.amjpathol.org). In summary, neither this study nor other previous research found a consistent alteration of IGF1R protein levels in local prostate cancer areas compared with benign prostate areas using immunohistochemistry.

INSR protein levels in prostate tissues have to date not been intensively investigated. We found INSR protein levels predominantly located in epithelial cells (Figure 2A). INSR protein levels were heterogeneous within and between prostate tissues of single patients. An overall quantification of INSR mean staining intensities showed no difference in benign and cancer areas of the prostate (Figure 2B). In several prostate areas, we observed, however, higher INSR staining intensities in epithelial glands adjacent to cancer than in the cancer areas themselves (Figure 2C). Antibody specificity controls were included in the study (see Supplemental Figure S3 at http://ajp. amjpathol.org).

Apart from the receptors, all IGF proteins are secretory factors that are secreted in the extracellular space. Extracellular IGF factors can be taken up by prostate epithelial cells, as we have shown for IGFBP3. ${ }^{26}$ We performed immunohistochemistry for IGF2, IGFBP2, IGFBP3, and IGFBP5 and noted a predominant epithelial localiza- 


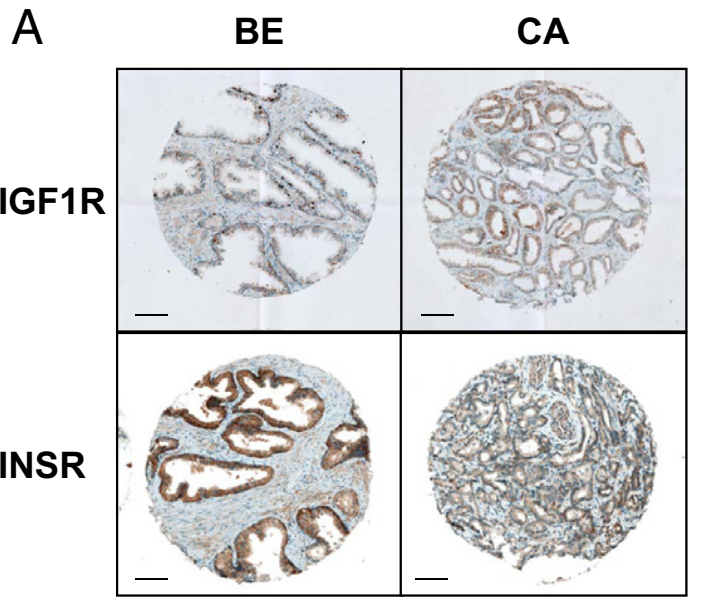

B
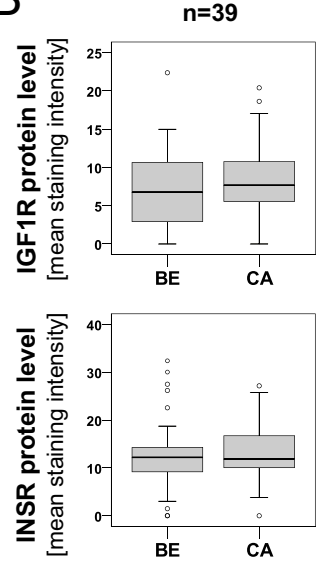

C INSR

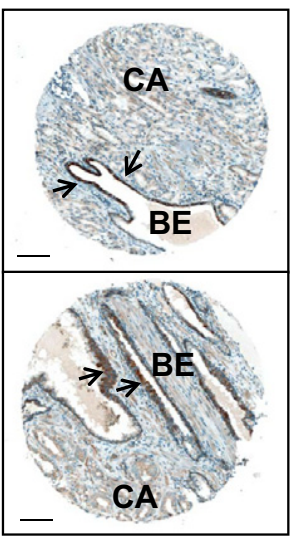

Figure 2. Immunohistochemical staining of IGF1R and INSR in prostate tissue. A: IGF1R and INSR are located predominantly in the epithelial cells. B: Staining quantification revealed comparable overall IGF1R and INSR mean staining intensities in benign epithelial cell (BE) and cancer cell (CA) areas of prostate tissues. C: In local areas high INSR staining intensities were detected in BE adjacent to CA. Immunohistochemistry on human prostate tissue was performed with quantitative analysis using TissueFAXS and HistoQuest immunohistochemistry analysis software. Immunohistochemistry staining is shown for anti-IGF1R antibody sc-713 and anti-INSR antibody sc-711. Scale bar $=100 \mu \mathrm{m}$.

tion of these proteins in prostate tissue (see Supplemental Figure S6 at http://ajp.amjpathol.org).

Summarized, our protein analysis on prostate tissue using immunohistochemistry revealed that i) IGF proteins are present in prostate tissues and are predominantly located in prostate epithelium, ii) IGF proteins levels are not significantly changed in local prostate cancer compared with benign prostate epithelium, and iii) IGF protein levels determined by immunohistochemistry do not reflect mRNA expression levels in prostate tissue. We conclude from these data that immunohistochemistry alone does not reflect IGF expression levels and is probably not sufficient to assess the activity of the IGF axis in the prostate.

\section{IGF Axis Is Induced during Benign Prostate Epithelial Differentiation}

In contrast to other tumors, where the IGF axis was shown to be up-regulated and required for oncogenic transformation, ${ }^{27,28}$ we found that in local prostate cancer the mRNA expression of the IGF axis is down-regulated. Previous reports have suggested that the IGF axis is not an oncogenic driver in prostate cancer but is required to maintain tissue homeostasis and a differentiated phenotype in the normal prostate. ${ }^{29,30}$ We hypothesized that down-regulation of IGF1, IGF2, IGF1R, and INSR mRNA in local prostate cancer is driven by cellular dedifferentiation. To test whether the IGF axis is regulated during prostate differentiation, we induced luminal differentiation in cellular models of benign prostate epithelial cells and investigated the effect on the IGF axis.

Primary cells are kept in media with very low calcium levels to avoid cellular differentiation induced by high calcium levels. ${ }^{31,32}$ The low calcium culture medium of EP156T cells (MCDB 153 with supplements; calcium, $0.03 \mathrm{mmol} / \mathrm{L})$ was changed to a high calcium medium (RPMI 1640 with 10\% fetal bovine serum; calcium, >0.42 $\mathrm{mmol} / \mathrm{L})$ to induce cellular differentiation. The change of the culture medium led to a rapid luminal differentiation of EP156T epithelial cells, observed by an alteration of cell morphologic findings (Figure 3A), reduction of proliferation (Figure 3B), up-regulation of luminal cell markers (KRT18 and AR), and down-regulation of a basal cell marker (p63) (Figure 3, A, C, and D; exact-fold changes and $P$ values in Supplemental Table S7 at http://ajp. amjpathol.org). Interestingly, p63 was not only down-regulated but also exported from the nucleus in differentiated EP156T (Figure 3A). In differentiated EP156T cells, all proteins of the IGF axis, including IGF2, IGF1R, IGF2R, INSR, and IGFBP3-6, were significantly up-regulated at mRNA levels, with the exception of IGFBP2, which was down-regulated, and IGF1, which was not expressed at detectable levels (Figure 3C, see Supplemental Table S7 at http://ajp.amjpathol.org). Concordant to the mRNA data, protein levels of differentiation markers (KRT 8 and KRT18) and secretors IGF factors (eg, IGFBP3) were up-regulated in differentiated EP156T cells. Protein levels of IGF1R and INSR, however, remained unchanged and did not correlate with mRNA levels (Figure 3D). These data are in line with our observations in prostate tissue, where protein levels of IGF1R and INSR did not reflect mRNA expression levels. Collectively, we determined an up-regulation of the IGF axis (with the exception of IGFBP2) in differentiated EP156T.

Next, we validated our results from EP156T cells using RWPE-1 as an independent cellular model. When the low calcium growth medium of RWPE-1 was changed to a high calcium medium, RWPE-1 cells changed their morphologic findings and up-regulated the luminal marker KRT18 (Figure 3, A, C, and D, exact-fold changes and $P$ values in Supplemental Table S8 at http://ajp.amjpathol. org). The expression and localization of the basal cell marker p63 remained unchanged. The very low AR level (near detection limit of quantitative PCR) also remained unchanged (Figure 3C). Cell proliferation was not re- 


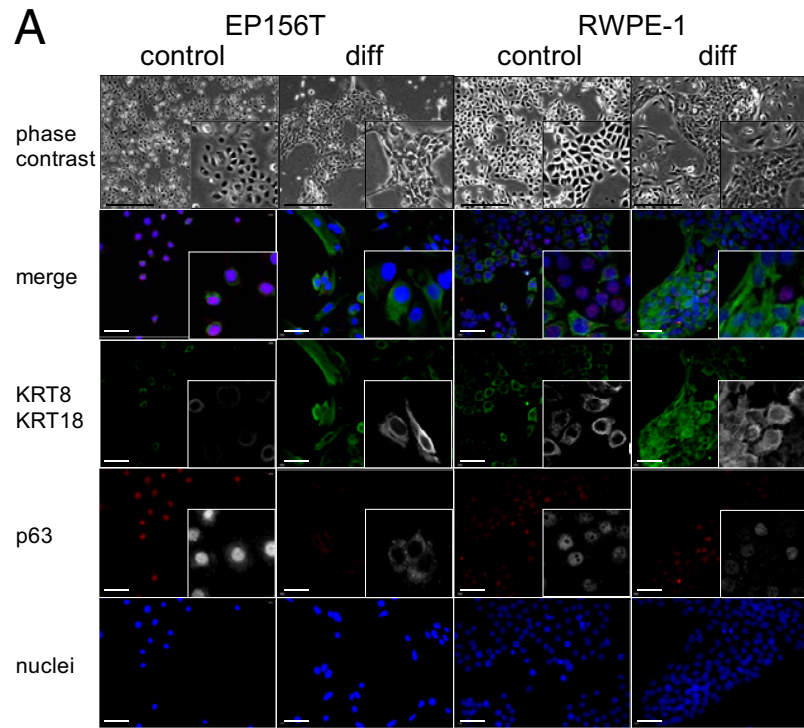

B

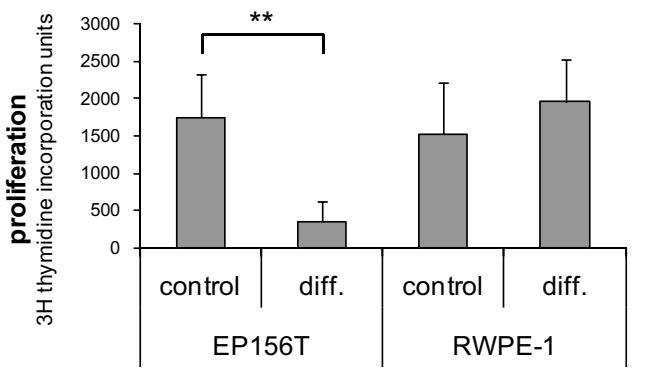

Figure 3. The IGF axis is up-regulated during normal epithelial differentiation. Differentiation was induced in cellular models of benign prostate epithelial cells (EP156T and RWPE-1). EP156T differentiated, whereas RWPE-1 cells differentiated only partially. A: Cellular morphologic findings were changed in differentiated epithelial cells. Staining of luminal (cytokeratin 8, KRT8; cytokeratin 18, KRT18) and basal (p63) cell markers revealed a basal to luminal differentiation. B: Proliferation was reduced in differentiated EP156T but not in partially differentiated RWPE-1. C: mRNA expression levels of differentiation markers confirmed differentiation of EP156T and partial differentiation of RWPE-1. The expression of the IGF axis, with the exception of IGFBP2, was upregulated in differentiated epithelial cells. D: Up-regulation of luminal differentiation markers (KRT8 and KRT18) and secretory IGF factors (IGFBP3) was confirmed at the protein level, whereas IGF1R and INSR protein levels remained unchanged in differentiated epithelial cells. Prostate epithelial cells were differentiated in medium containing high calcium levels (calcium, $>0.4 \mathrm{mmol} / \mathrm{L}$ ). Cellular morphologic findings were determined by phase contrast microscopy, protein localization by immunofluorescent staining, proliferation by $3 \mathrm{H}$ incorporation assay, mRNA levels by quantitative PCR (endogenous control, HPRT1), and protein levels by Western blot (endogenous control, GAPDH). Error bars represent SD of five independent experiments. Student's $t$-test; ${ }^{*} P<0.05$; ${ }^{* * *} P<0.01 ;{ }^{* * * *} P<0.001$. Diff., differentiated cells. Scale bar $=50 \mu \mathrm{m}$.

duced. These data indicate that full luminal differentiation of RWPE-1 cells could not be induced by high calcium levels. Strong up-regulation of the luminal markers KRT8 and KRT18 (Figure 3A and D) revealed, however, that the
C

control diff.

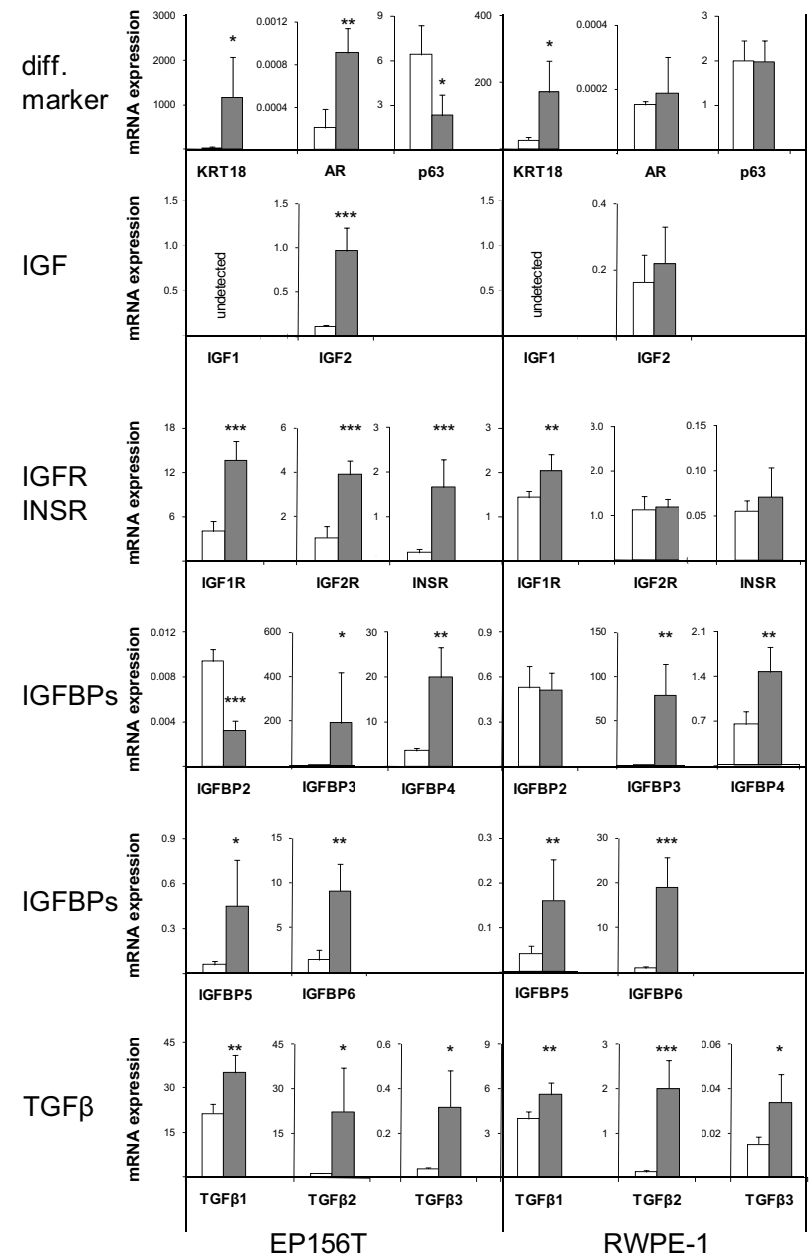

D

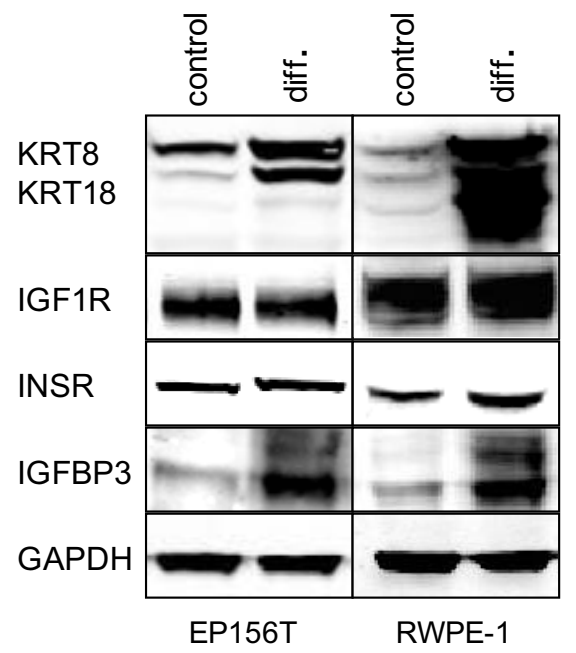

cells underwent a partial differentiation process. In partially differentiated RWPE-1 cells, IGF1R and IGFBP3-6 were up-regulated at the mRNA level. Similarly to EP156T, partially differentiated RWPE-1 cells did not up- 
regulate IGFBP2 and did not express IGF1 at detectable amounts. In contrast to EP156T, IGF2, IGF2R, and INSR, mRNA levels remained unchanged in partially differentiated RWPE-1. This discrepancy most likely emerges because only a partial and not a full differentiation could be induced in RWPE-1. Similarly to EP156T, protein levels of KRT8, KRT18, and IGFBP3 were up-regulated in partially differentiated RWPE-1, whereas protein levels of IGF1R and INSR remained unchanged (Figure 3D). Altogether, a (partial) up-regulation of the IGF axis was observed in partially differentiated RWPE-1. Collectively, our data provide evidence that the IGF axis (except IGFBP2) is induced during normal luminal differentiation of prostate epithelial cells.

\section{IGF Axis Is Reduced in Transformed Prostate Epithelial Cell Lines}

Next we examined whether transformation of benign epithelial cells leads to modulation of the IGF axis. We compared IGF expression in primary benign prostate epithelial cells, different models of immortalized or transformed prostate epithelial cells, and our differentiation model. Primary epithelial cells were isolated by standard selection cell culture from benign prostate areas of four different prostate cancer patients. ${ }^{23}$ These culture conditions were described to lead to a selection of basal prostate epithelial cells. ${ }^{33,34}$ EP156T (benign prostate epithelial cells immortalized by telomerase overexpression), ${ }^{24}$ RWPE-1 (benign prostate epithelial cells transformed by human papillomavirus 18 oncogene overexpression), ${ }^{25}$ and RWPE-2 (derivative of RWPE-1; generated by adding a second oncogene, V-Ki-ras, which can initiate tumors in nude mice) ${ }^{25}$ were used as models for cells representing different steps of transformation, whereas differentiated EP156T (cultured in high calcium medium) were included as a model of differentiated luminal epithelial cells.

We found the highest expression levels of all proteins of the IGF axis in differentiated EP156T, with the exception of IGFBP2, which was lowest in differentiated EP156T, and IGF2, which was produced at comparable amounts by primary epithelial cells and RWPE-2 (Figure 4). When we compared primary epithelial cells and telomerase immortalized EP156T to oncogene-transformed RWPE-1 and RWPE-2, we found a reduced expression of IGF1R, IGF2R, INSR, IGFBP3, IGFBP4, IGFBP5, and IGFBP6 in the oncogene-transformed cells RWPE-1 and RWPE-2 (Figure 4; see also Supplemental Table S9 at http://ajp.amjpathol.org). IGF1R and IGF2 were lowest in RWPE-1 but increased again in RWPE-2, indicating that possibly in aggressive (or metastatic) prostate cancer the IGF axis is induced again (Figure 4; see also Supplemental Table S10 at http://ajp.amjpathol.org). In summary, we found the highest expression levels of IGF proteins in differentiated benign prostate epithelial cells. Reduced differentiation (basal cell phenotype) and transformation of benign prostate epithelial cells led to a reduction of IGF axis expression levels. Enhancement of a progressed
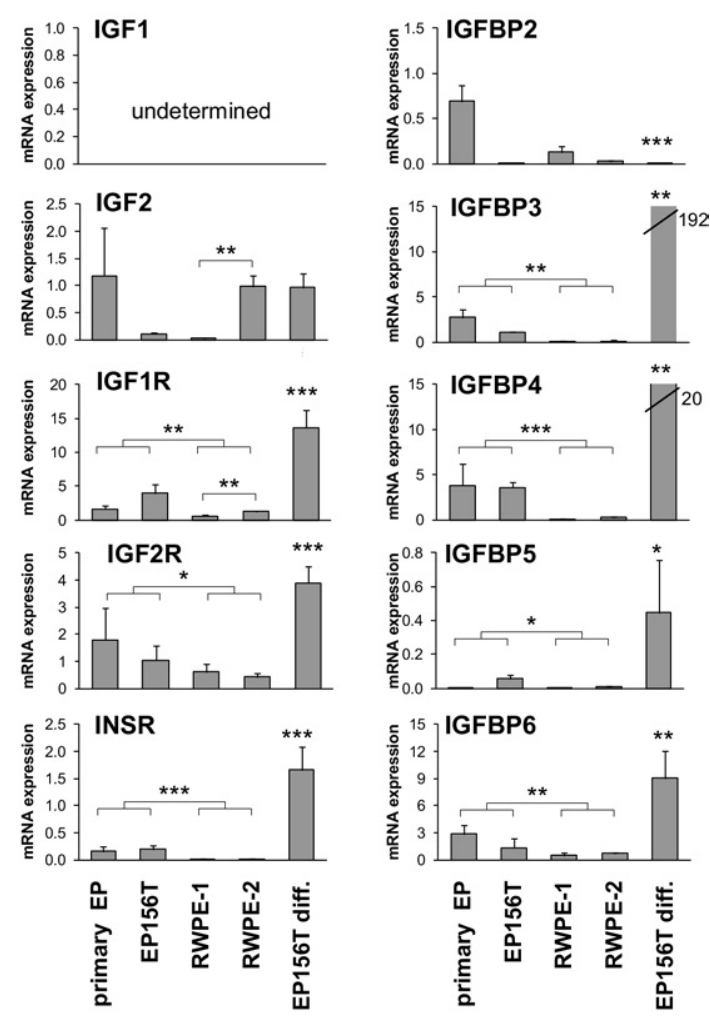

transformation:
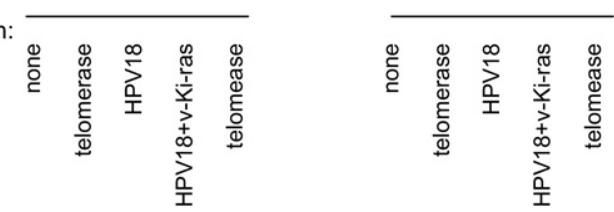

Figure 4. The expression of the IGF axis is reduced in oncogene-transformed prostate epithelial cells. Expression levels of all proteins of the IGF axis (except IGFBP2 and IGF2) were reduced in oncogene-transformed epithelial cells (RWPE-1 and RWPE-2) compared with primary epithelial cells (primary EP) and telomerase-transformed epithelial cells (EP156T). The highest IGF axis expression levels were detected in differentiated EP156T (EP156T diff.; except IGFBP2 and IGF2). IGF1R and IGF2 mRNA expression was elevated in tumorigenic RWPE-2 compared with RWPE-1. Primary EPs were isolated from benign prostate tissue of four prostate cancer patients using cell-selective culture conditions. mRNA expression levels were measured by quantitative PCR (endogenous control, HPRT1). Error bars represent SD of four independent primary EP (isolated from four different patients) or four independent experiments (cell lines). Student's $t$-test; significant differences were only marked when related to the described findings: ${ }^{*} P<0.05 ;{ }^{* * *} P<0.01 ;{ }^{* * * *} P<0.001$.

oncogenic phenotype (RWPE-2 cells) induced growth factor and receptor levels.

\section{IGF Axis Is Up-Regulated after Exposure to TGF- $\beta$}

TGF $\beta$ was identified as one of the key players of normal prostate epithelial differentiation ${ }^{35,36}$ and was also described to induce the expression of IGFBP3. ${ }^{26,37} \mathrm{We}$ therefore investigated whether TGF- $\beta$ influences the expression of other members of the IGF axis beside IGFBP3 and asked whether TGF- $\beta$ could account for the regulation of the IGF axis observed in local tumors and the cell culture differentiation model. 
mRNA expression analysis of TGF- $\beta$ in microdissected prostate tissues revealed that TGF- $\beta 1$, TGF- $\beta 2$ (not significant), and TGF- $\beta 3$ are down-regulated in local prostate cancer compared with matched benign samples (Figure 1D; see also Supplemental Table S1 at $h$ ttp://ajp.amjpathol.org). TGF- $\beta 2$ and TGF- $\beta 3$ were down-regulated in cancer-associated stroma compared with matched benign epithelium-associated stroma (Figure 1D; see also Supplemental Table S2 at http://ajp.amjpathol.org). Thus, we found that TGF- $\beta$ factors are down-regulated in local prostate cancer tissue in both the cancer cells and the cancer-associated stroma.

Next, we studied whether TGF- $\beta$ is regulated during benign prostate differentiation. For this analysis, we used our in vitro differentiation model and analyzed TGF- $\beta$ expression levels in differentiated EP156T and partially differentiated RWPE-1 cells. We found TGF$\beta 1$, TGF- $\beta 2$, and TGF- $\beta 3$ mRNA up-regulated during normal prostate epithelial differentiation in both cellular models (Figure 3C; see also Supplemental Table S7 and Supplemental Table S8 at $h$ ttp://ajp.amjpathol.org), indicating that the TGF- $\beta$ axis is involved in normal prostate differentiation.

Both the IGF axis and TGF- $\beta$ were up-regulated during normal prostate epithelial differentiation and down-regulated in prostate cancer tissue. Hence, we examined whether a link between TGF- $\beta$ and the IGF axis exists. We treated prostate cells with TGF- $\beta$ and analyzed the expression of the IGF axis. We compared benign (EP156T, RWPE-1) and malignant (Du145, LNCaP, PC3, VCaP) prostate cells. Although EP156T, RWPE-1, Du145, and PC3 responded to TGF- $\beta$ treatment with reduced proliferation, $\mathrm{LNCaP}$ and $\mathrm{VCaP}$ did not (Figure $5 \mathrm{~A}$; data shown for EP156T, PC3, and VCaP). Expression analysis of TGF- $\beta$ receptors revealed that the TGF- $\beta$ unresponsive cell lines (LNCaP and VCaP) express very low TGF- $\beta$ receptor levels (Figure 5B, data shown for EP156T, PC3, and $\mathrm{VCaP}$ ). The expression of all proteins of the IGF axis, again with the exception of IGFBP2, was up-regulated in TGF- $\beta$ responsive prostate cells on TGF- $\beta$ treatment (Figure 5C; see also Supplemental Table S11 and Supplemental Table S12 at $h$ ttp://ajp.amjpathol.org; data shown for EP156T and PC3). Although the direction of the regulation was always the same, a high overall variation in the level of induction of IGF factors after TGF- $\beta$ treatment in the single experiments (eg, induction of IGFBP3 in EP156T was twofold in the first experiment and 30-fold in a second experiment) was observed, resulting in high SDs. No difference in IGF regulation was observed between benign cell lines and cancer cell lines, and no difference was observed among TGF- $\beta 1$, TGF- $\beta 2$, and TGF- $\beta 3$ treatment (data not shown). Cell lines with very low TGF- $\beta$ receptor levels (LNCaP and VCaP) did not respond to TGF- $\beta$ treatment by up-regulation of the IGF axis (Figure $5 \mathrm{C}$, data shown for $\mathrm{VCaP}$ ).

Collectively, we show that both the IGF axis and TGF- $\beta$ are up-regulated during normal prostate epithelial differentiation and down-regulated in local prostate cancer. After TGF- $\beta$ treatment, the expression of the IGF axis was enhanced in prostate cells expressing TGF- $\beta$ receptors, with the exception of IGFBP2. These data indicate a regulatory influence of TGF- $\beta$ on the expression of the IGF axis.

\section{Discussion}

The IGF axis is extensively investigated in cancer research. It exerts pivotal functions in normal and cancer development and is currently under investigation as a molecular cancer target in a variety of different cancers, including prostate cancer. ${ }^{1,2,6,7}$ In prostate cancer tissue, the expression of the IGF axis has to date been investigated using mainly immunohistochemical analysis. In most studies, only one or a few members of the IGF axis were analyzed. In addition, the results from these analyses often failed to be consistent. IGF1R levels were reported to be down-regulated, ${ }^{14}$ up-regulated, ${ }^{15,16}$ or not changed ${ }^{17,18}$ in local prostate cancer. The IGF1R is a tyrosine kinase receptor. Tyrosine kinase receptors are internalized and degraded on growth factor stimulation. ${ }^{38,39}$ Thus, IGF1R protein levels are affected by receptor activation and turnover and do not always reflect receptor expression levels. In addition, immunohistochemistry results can be influenced by a variety of technical factors, including tissue storage and fixation conditions, antigen retrieval protocols, antibody specificity, antibody detection systems, and other methodologic factors. ${ }^{40}$ Additional bias may be introduced by quantification of immunohistochemical staining because both semiquantitative grading by pathologists and quantitative analyses by quantification software have their limitations. ${ }^{41}$ All members of the IGF axis apart from the receptors are secretory proteins. Their location often differs from their site of production. Altogether we consider immunohistochemistry not to be an appropriate tool to investigate the expression of the IGF axis.

We present an expression analysis on microdissected prostate tissue using quantitative PCR. Quantitative PCR measures the mRNA expression of proteins in the protein-producing cells, uses target-specific primers reaching magnitudes of higher specificities than antibodies, and is quantified automatically based on endogenous controls as reference signals. All members of the IGF axis were included in our study, and epithelial and stromal tissue areas were distinguished in both benign and local cancer areas to measure the expression of IGF proteins at their side of production. We report that IGF1, IGF2, IGF1R, and INSR expression is down-regulated in local prostate cancer tissue areas compared with matched benign tissue areas.

These results are astonishing. Considering the high amounts of in vitro data showing that the IGF1R is a mediator of proliferation and protects cancer cells from apoptosis, the down-regulation of the IGF axis in local prostate cancer was not expected. Our data are, however, in line with previous reports suggesting that the IGF1R is not an oncogenic driver in prostate cancer: Although mouse fibroblasts lacking IGF1R cannot be transformed by known oncogenes, such as SV40 T antigen, papillomavirus E5, and overexpression of Ras ${ }^{42}$ in 
A

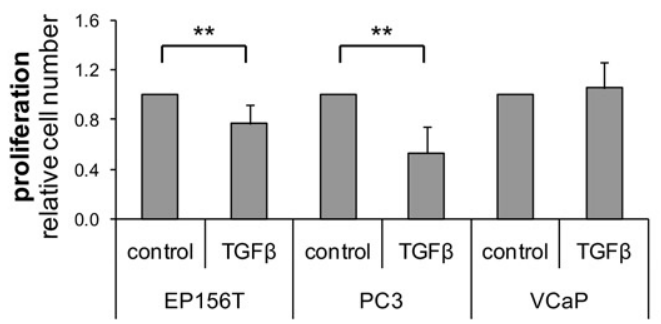

B

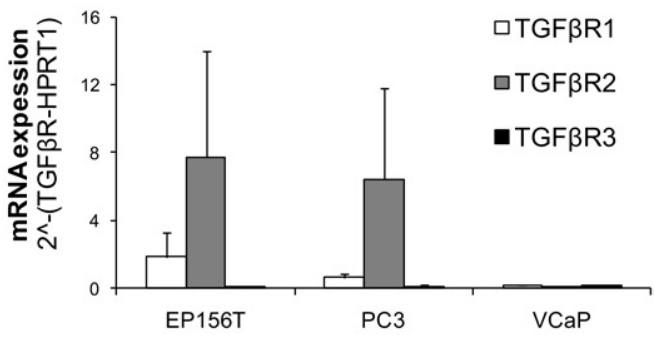

C

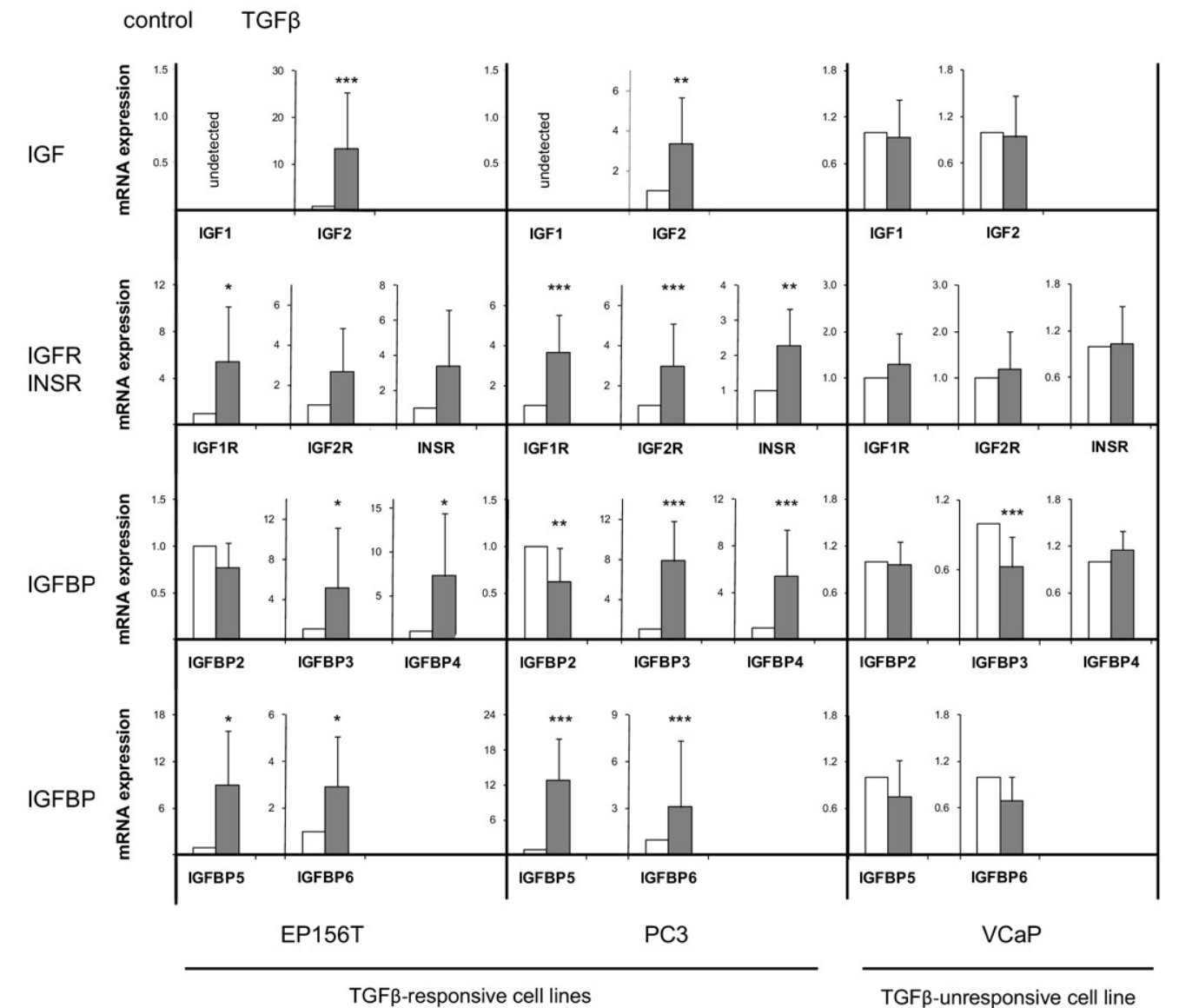

Figure 5. The IGF axis is up-regulated after exposure to TGF- $\beta$. A: Cellular proliferation was reduced after TGF- $\beta$ treatment in EP156T and PC 3 cells. B: Cell lines not responding to TGF- $\beta$ treatment with reduced proliferation (VCaP) do not express TGF- $\beta$ receptors. C: In TGF- $\beta$ responsive cell lines the IGF axis was up-regulated after TGF- $\beta$ treatment, with the exception of IGFBP2, which was down-regulated. Benign prostate epithelial cells (EP156T shown) and prostate cancer cells (PC3 and VCaP shown) were treated with TGF- $\beta$ for 24 hours. Cellular proliferation was investigated by total cell number determination and mRNA expression by quantitative PCR (endogenous control, HPRT1). Error bars represent SD of three (A-B) or five (C) independent experiments. Mann-Whitney $U$-test; ${ }^{*} P<0.05 ;{ }^{* * *} P<0.01 ;{ }^{* * * *} P<0.001$.

prostate epithelial cells, reexpression of the IGF1R inhibited the malignant phenotype of a SV40-transformed cell line. ${ }^{29}$ In mouse models, overexpression of a constitutively activated IGF1R was shown to be sufficient to cause mammary epithelial cell transformation, ${ }^{27,28}$ whereas epithelial specific deletion of IGF1R accelerated the emergence of aggressive prostate cancer when p53 activity was compromised. ${ }^{30}$ Altogether these and our data point to the fact that the IGF1R does not act as an oncogene in the prostate and is not overexpressed in local prostate cancer.
We have only investigated local prostate cancer in this study. The expression of the IGF axis in advanced metastatic prostate cancer supposedly differs from the expression in local cancer, and although the IGF axis does not seem to be up-regulated during prostate cancer development, it may well be important for prostate cancer progression. Our finding that RWPE-2, a human papillomavirus 18 and V-Ki-ras oncogene transformed cell line that is tumorigenic in mice ${ }^{25}$ has an increased expression of IGF2 and IGF1R compared with its parental nontumorigenic cell line RWPE-1 indicates a role of the IGF 
axis in advanced prostate cancer. Literature data on IGF axis expression in advanced prostate cancer are similar to data on local prostate cancer, often contradictory, and rely mainly on immunohistochemistry staining. IGF1R levels were found to be down-regulated, ${ }^{17}$ unchanged, or up-regulated ${ }^{15,43,44}$ in metastatic prostate cancer compared with local prostate cancer. Except for one study, ${ }^{17}$ immunohistochemistry was used for IGF1R detection. Low sample numbers and heterogeneous staining pattern described among different patients ${ }^{15}$ and serial samples of the same patient ${ }^{44}$ further exacerbate the interpretation of the results. Data from mouse models were also not able to entirely clarify the role of the IGF axis in advanced prostate cancer: In some xenograft studies, IGF signaling was found to be up-regulated in prostate cancer metastases, ${ }^{45}$ whereas in others IGF1R levels progressively decreased as prostate cancer cells became more tumorigenic and metastatic. ${ }^{46}$ In different transgenic mouse models, IGF levels were decreased in prostate cancer cells of metastatic tissues, ${ }^{47}$ and IGF1R was even reported to protect from development of aggressive prostate cancer. ${ }^{30}$ In general, data on the implication of the IGF axis in human prostate cancer progression are still inconclusive and further examinations are implicitly needed.

IGF1R was recently found to be located in the nucleus of many cancer cells, including prostate cancer cells, and a potential nuclear function of the IGF1R in cancer cells was proposed. ${ }^{47,48}$ It seems possible that differential receptor downstream signals and nuclear translocation of the IGF1R have a higher impact on IGF1R signaling in cancer cells than receptor expression levels alone.

This study did not account for serum levels of secretory IGF factors, including IGF1, IGF2, and IGFBP1 through IGFBP16. The serum represents an additional source of IGF factors in the prostate. High serum IGF1 levels were significantly associated with prostate cancer in several independent studies. ${ }^{49-51}$ The biological impact of this association is not understood so far. Although the association between high serum IGF1 and prostate cancer is clear, some concerns have been raised about whether the alteration of IGF1 serum levels in prostate cancer patients is high enough to have biological impacts on prostate cells. The amounts of locally produced IGF1 and IGF2 in prostate tissue may exceed the levels coming from the serum.

The IGF axis is important for normal development, tissue homeostasis, and differentiation; hence, we investigated whether the IGF axis is regulated during normal epithelial differentiation of the prostate. In vitro models for prostate epithelial differentiation are rare, and we were not able to induce cellular differentiation in conventional models, like the spheroid formation assay. Thus, we developed a new and technically easy in vitro differentiation model, where we induced cellular differentiation by elevated calcium levels. We found the mRNA levels of all members of the IGF axis increased after normal prostate epithelial differentiation. The only exception was IGFBP2, which did not follow the regulation of the IGF axis and remains an interesting candidate for further functional investigations. When we compared the expression of the
IGF axis in oncogene-transformed cell lines deriving from benign epithelial cells to benign primary epithelial and telomerase-immortalized epithelial cells, we observed a down-regulation of the IGF axis in the oncogene-transformed lines. These results are consistent with our observation in human prostate tissue, where the expression of the IGF axis was reduced in local prostate cancer cells. TGF- $\beta$, a major differentiation factor of the prostate, upregulated the expression of the IGF axis (again with the exception of IGFBP2). Altogether our experiments confirm that the IGF axis is involved in normal epithelial differentiation of the prostate. Dedifferentiation of cancer cells may down-regulate IGF axis members in local prostate cancer.

Our study has several strengths and limitations. The robust methods can certainly be considered a major strength of our analysis. Quantitative PCR is superior to conventional expression analysis using microarray technologies in terms of reduced sensitivity to poor RNA quantity and quality. This allowed us to use microdissected tissue with low RNA amounts, like stromal tissues. Combined with an accurate tissue selection and an optimized microdissection technology, we were able to isolate all four different cell populations (cancer, cancer-associated stromal, benign epithelial, and benign epithelial-associated cells) from one tissue slide, thereby avoiding random effects by tissue heterogeneities. Superior to previous studies, we included all members of the IGF axis in our study, which allowed us to get a comprehensive picture on the IGF axis. Finally, we linked our observations to functional aspects of the IGF axis using a new and easy prostate differentiation model and propose a functional interpretation of our data. The time-consuming separation of different cell populations by LCM led to a relatively small sample size of the expression analysis, which can be considered a limitation of our study. To overcome this problem, we tightly controlled our analysis (see Supplemental Figure S2 at http://ajp.amjpathol.org) and confirmed our results using samples from an independent LCM approach to avoid methodologic bias (Figure 1). Furthermore, this study is limited to local prostate cancer and benign prostate. The expression of the IGF axis in advanced and metastatic prostate cancer still needs to be elucidated.

Altogether our data point out that the IGF axis is a tightly regulated molecular network that exerts pivotal physiologic effects. It seems that overexpression of IGF factors is not required for prostate cancer emergence. Our data underline the importance of the IGF axis in normal physiology. A pathway with pivotal physiologic functions, such as the IGF axis, represents a challenging cancer target. The IGF axis does not seem to be an oncogenic driver in all cancers entities and cancer stages. Consequently, targeting the IGF1R for cancer therapy seems not to be appropriate for these types of cancer. Precise target validation before treatment remains essential to select patients profiting from a molecular therapy, such as the anti-IGF1R therapy, thereby reducing adverse effects and increasing treatment responses. 


\section{Acknowledgments}

We acknowledge Iris E. Eder, Florian Kronenberg, and Martin Puhr for helpful suggestions; Bill Watson and Antoinette Perry for providing RWPE-1 cells; Walther Parson for forensic DNA fingerprinting; and Christof Seifarth, Irma Sottsas, Karin Unterberger, Stefan Coassin, Gabi Dobler, Gertraud Erhart, Victoria Herzog, and Eberhard Steiner for excellent technical assistance.

\section{References}

1. Gualberto A, Pollak M: Emerging role of insulin-like growth factor receptor inhibitors in oncology: early clinical trial results and future directions. Oncogene 2009, 28:3009-3021

2. Heidegger I, Pircher A, Klocker H, Massoner P: Targeting the insulinlike growth factor network in cancer therapy. Cancer Biol Ther 2011, 11:701-707

3. Pfizer. Pfizer Discontinues A Phase 3 Trial Of Figitumumab In NonSmall Cell Lung Cancer (NSCLC) For Futility [press release]. December 29, 2009. Available online at http://www.pfizer.com/news/press_ releases/pfizer_press_release_archive.jsp\#guid $=20091229005376 \mathrm{en} \&$ source $=$ RSS_2009\&page $=1$

4. Pfizer. Pfizer Discontinues A Phase 3 Study Of Figitumumab In Previously Treated Patients With Advanced Non-Small Cell Lung Cancer [press release]. March 11, 2010. Available online at http://www.pfizer com/news/press_releases/pfizer_press_release_archive.jsp\#guid= 20100311006790en\&source $=$ RSS_2010\&page $=9$

5. Jassem J, Langer C, Karp D, Mok T, Benner R, Green S: Randomized, open label, phase III trial of figitumumab in combination with paclitaxel and carboplatin versus paclitaxel and carboplatin in patients with non-small cell lung cancer (NSCLC). J Clin Oncol 2010, 28:2010

6. Pollak M: Insulin and insulin-like growth factor signalling in neoplasia. Nat Rev Cancer 2008, 8:915-928

7. Massoner P, Ladurner-Rennau M, Eder IE, Klocker H: Insulin-like growth factors and insulin control a multifunctional signalling network of significant importance in cancer. Br J Cancer 2010, 103:1479_ 1484

8. LeRoith $D$, Roberts CT Jr.: The insulin-like growth factor system and cancer. Cancer Lett 2003, 195:127-137

9. Pandini G, Frasca F, Mineo R, Sciacca L, Vigneri R, Belfiore A: Insulin/insulin-like growth factor I hybrid receptors have different biological characteristics depending on the insulin receptor isoform involved. J Biol Chem 2002, 277:39684-39695

10. Kawada M, Inoue H, Masuda T, Ikeda D: Insulin-like growth factor I secreted from prostate stromal cells mediates tumor-stromal cell interactions of prostate cancer. Cancer Res 2006, 66:4419-4425

11. Parrizas $M$, LeRoith $D$ : Insulin-like growth factor-1 inhibition of apoptosis is associated with increased expression of the bcl-xL gene product. Endocrinology 1997, 138:1355-1358

12. Marelli MM, Moretti RM, Procacci P, Motta M, Limonta P: Insulin-like growth factor-I promotes migration in human androgen-independent prostate cancer cells via the alphavbeta3 integrin and PI3-K/Akt signaling. Int J Oncol 2006, 28:723-730

13. Connolly JM, Rose DP: Regulation of DU145 human prostate cancer cell proliferation by insulin-like growth factors and its interaction with the epidermal growth factor autocrine loop. Prostate 1994, 24:167175

14. Tennant MK, Thrasher JB, Twomey PA, Drivdahl RH, Birnbaum RS, Plymate SR: Protein and messenger ribonucleic acid (mRNA) for the type 1 insulin-like growth factor (IGF) receptor is decreased and IGF-II mRNA is increased in human prostate carcinoma compared to benign prostate epithelium. J Clin Endocrinol Metab 1996, 81:37743782

15. Hellawell GO, Turner GD, Davies DR, Poulsom R, Brewster SF, Macaulay VM: Expression of the type 1 insulin-like growth factor receptor is up-regulated in primary prostate cancer and commonly persists in metastatic disease. Cancer Res 2002, 62:2942-2950

16. Liao Y, Abel U, Grobholz R, Hermani A, Trojan L, Angel P, Mayer D: Up-regulation of insulin-like growth factor axis components in human primary prostate cancer correlates with tumor grade. Hum Pathol 2005, 36:1186-1196

17. Chott A, Sun Z, Morganstern D, Pan J, Li T, Susani M, Mosberger I, Upton MP, Bubley GJ, Balk SP: Tyrosine kinases expressed in vivo by human prostate cancer bone marrow metastases and loss of the type 1 insulin-like growth factor receptor. Am J Pathol 1999, 155:12711279

18. Cox ME, Gleave ME, Zakikhani M, Bell RH, Piura E, Vickers E, Cunningham M, Larsson O, Fazli L, Pollak M: Insulin receptor expression by human prostate cancers. Prostate 2009, 69:33-40

19. Horninger W, Reissigl A, Rogatsch H, Volgger H, Studen M, Klocker $\mathrm{H}$, Bartsch G: Prostate cancer screening in the Tyrol. Austria: experience and results. Eur J Cancer 2000, 36:1322-1335

20. Kounnis V, loachim E, Svoboda M, Tzakos A, Sainis I, Thalhammer T, Steiner G, Briasoulis E: Expression of organic anion-transporting polypeptides $1 \mathrm{~B} 3,1 \mathrm{~B} 1$, and $1 \mathrm{~A} 2$ in human pancreatic cancer reveals a new class of potential therapeutic targets. Onco Targets Ther 2011, 4:27-32

21. Yao Z, Fenoglio S, Gao DC, Camiolo M, Stiles B, Lindsted T, Schlederer M, Johns C, Altorki N, Mittal V, Kenner L, Sordella R: TGF-beta IL-6 axis mediates selective and adaptive mechanisms of resistance to molecular targeted therapy in lung cancer. Proc Natl Acad Sci U S A 2010, 107:15535-15540

22. Lv F, Qiu Y, Zhang Y, Liu S, Shi J, Liu Y, Zheng D: Adeno-associated virus-mediated anti-DR5 chimeric antibody expression suppresses human tumor growth in nude mice. Cancer Lett 2011, 302:119-127

23. Cronauer MV, Eder IE, Hittmair A, Sierek G, Hobisch A, Culig Z, Thurnher M, Bartsch G, Klocker H: A reliable system for the culture of human prostatic cells. In Vitro Cell Dev Biol Anim 1997, 33:742-744

24. Kogan I, Goldfinger N, Milyavsky M, Cohen M, Shats I, Dobler G, Klocker H, Wasylyk B, Voller M, Aalders T, Schalken JA, Oren M, Rotter V: hTERT-immortalized prostate epithelial and stromal-derived cells: an authentic in vitro model for differentiation and carcinogenesis. Cancer Res 2006, 66:3531-3540

25. Bello D, Webber MM, Kleinman HK, Wartinger DD, Rhim JS: Androgen responsive adult human prostatic epithelial cell lines immortalized by human papillomavirus 18. Carcinogenesis 1997, 18:12151223

26. Massoner P, Haag P, Seifarth C, Jurgeit A, Rogatsch H, Doppler W, Bartsch G, Klocker H: Insulin-like growth factor binding protein-3 (IGFBP-3) in the prostate and in prostate cancer: local production, distribution and secretion pattern indicate a role in stromal-epithelial interaction. Prostate 2008, 68:1165-1178

27. Jones RA, Campbell CI, Gunther EJ, Chodosh LA, Petrik JJ, Khokha R, Moorehead RA: Transgenic overexpression of IGF-IR disrupts mammary ductal morphogenesis and induces tumor formation. Oncogene 2007, 26:1636-1644

28. Kim HJ, Litzenburger BC, Cui X, Delgado DA, Grabiner BC, Lin X, Lewis MT, Gottardis MM, Wong TW, Attar RM, Carboni JM, Lee AV: Constitutively active type I insulin-like growth factor receptor causes transformation and xenograft growth of immortalized mammary epithelial cells and is accompanied by an epithelial-to-mesenchymal transition mediated by NF-kappaB and snail. Mol Cell Biol 2007, 27:3165-3175

29. Plymate SR, Bae VL, Maddison L, Quinn LS, Ware JL: Reexpression of the type 1 insulin-like growth factor receptor inhibits the malignant phenotype of simian virus $40 \mathrm{~T}$ antigen immortalized human prostate epithelial cells. Endocrinology 1997, 138:1728-1735

30. Sutherland BW, Knoblaugh SE, Kaplan-Lefko PJ, Wang F, Holzenberger M, Greenberg NM: Conditional deletion of insulin-like growth factor-I receptor in prostate epithelium. Cancer Res 2008, 68:34953504

31. Dalrymple S, Antony L, Xu Y, Uzgare AR, Arnold JT, Savaugeot J, Sokoll LJ, De Marzo AM, Isaacs JT: Role of notch-1 and E-cadherin in the differential response to calcium in culturing normal versus malignant prostate cells. Cancer Res 2005, 65:9269-9279

32. Peehl DM, Stamey TA: Serum-free growth of adult human prostatic epithelial cells. In Vitro Cell Dev Biol 1986, 22:82-90

33. Garraway LA, Lin D, Signoretti S, Waltregny D, Dilks J, Bhattacharya $\mathrm{N}$, Loda M: Intermediate basal cells of the prostate: in vitro and in vivo characterization. Prostate 2003, 55:206-218

34. Liu AY, Peehl DM: Characterization of cultured human prostatic epithelial cells by cluster designation antigen expression. Cell Tissue Res 2001, 305:389-397 
35. Li X, Wang Y, Sharif-Afshar AR, Uwamariya C, Yi A, Ishii K, Hayward SW, Matusik RJ, Bhowmick NA: Urothelial transdifferentiation to prostate epithelia is mediated by paracrine TGF-beta signaling. Differentiation 2009, 77:95-102

36. Untergasser G, Gander R, Rumpold H, Heinrich E, Plas E, Berger P: TGF-beta cytokines increase senescence-associated beta-galactosidase activity in human prostate basal cells by supporting differentiation processes, but not cellular senescence. Exp Gerontol 2003, 38:1179-1188

37. Rajah R, Valentinis B, Cohen P: Insulin-like growth factor (IGF)-binding protein-3 induces apoptosis and mediates the effects of transforming growth factor-beta1 on programmed cell death through a p53- and IGF-independent mechanism. J Biol Chem 1997, 272: 12181-12188

38. Romanelli RJ, LeBeau AP, Fulmer CG, Lazzarino DA, Hochberg A, Wood TL: Insulin-like growth factor type-I receptor internalization and recycling mediate the sustained phosphorylation of Akt. J Biol Chem 2007, 282:22513-22524

39. Levkowitz G, Waterman H, Zamir E, Kam Z, Oved S, Langdon WY Beguinot L, Geiger B, Yarden Y: C-Cbl/Sli-1 regulates endocytic sorting and ubiquitination of the epidermal growth factor receptor. Genes Dev 1998, 12:3663-3674

40. Yaziji H, Barry T: Diagnostic immunohistochemistry: what can go wrong?. Adv Anat Pathol 2006, 13:238-246

41. Taylor CR, Levenson RM: Quantification of immunohistochemistryissues concerning methods, utility and semiquantitative assessment II. Histopathology 2006, 49:411-424

42. Sell C, Rubini M, Rubin R, Liu JP, Efstratiadis A, Baserga R: Simian virus 40 large tumor antigen is unable to transform mouse embryonic fibroblasts lacking type 1 insulin-like growth factor receptor. Proc Natl Acad Sci U S A 1993, 90:11217-11221

43. Ryan CJ, Haqq CM, Simko J, Nonaka DF, Chan JM, Weinberg V, Small EJ, Goldfine ID: Expression of insulin-like growth factor-1 re- ceptor in local and metastatic prostate cancer. Urol Oncol 2007. 25:134-140

44. Turney BW, Turner GD, Brewster SF, Macaulay VM: Serial analysis of resected prostate cancer suggests up-regulation of type 1 IGF receptor with disease progression. BJU Int 2010, 107:1488-1499

45. Goya M, Miyamoto S, Nagai K, Ohki Y, Nakamura K, Shitara K, Maeda H, Sangai T, Kodama K, Endoh Y, Ishii G, Hasebe T, Yonou H, Hatano T, Ogawa Y, Ochiai A: Growth inhibition of human prostate cancer cells in human adult bone implanted into nonobese diabetic/severe combined immunodeficient mice by a ligand-specific antibody to human insulin-like growth factors. Cancer Res 2004, 64:6252-6258

46. Schayek H, Seti H, Greenberg NM, Sun S, Werner H, Plymate SR: Differential regulation of insulin-like growth factor-l receptor gene expression by wild type and mutant androgen receptor in prostate cancer cells. Mol Cell Endocrinol 2010, 323:239-245

47. Kaplan PJ, Mohan S, Cohen P, Foster BA, Greenberg NM: The insulin-like growth factor axis and prostate cancer: lessons from the transgenic adenocarcinoma of mouse prostate (TRAMP) model. Cancer Res 1999, 59:2203-2209

48. Aleksic T, Chitnis MM, Perestenko OV, Gao S, Thomas PH, Turner GD, Protheroe AS, Howarth M, Macaulay VM: Type 1 insulin-like growth factor receptor translocates to the nucleus of human tumor cells. Cancer Res 2010, 70:6412-6419

49. Renehan AG, Zwahlen M, Minder C, O'Dwyer ST, Shalet SM, Egger M: Insulin-like growth factor (IGF)-I. IGF binding protein-3, and cancer risk: systematic review and meta-regression analysis. Lancet 2004, 363:1346-1353

50. Sehat B, Tofigh A, Lin Y, Trocme E, Liljedahl U, Lagergren J, Larsson $\mathrm{O}$ : SUMOylation mediates the nuclear translocation and signaling of the IGF-1 receptor. Sci Signal 2010, 3:ra10

51. Shi R, Berkel HJ, Yu H: Insulin-like growth factor-I and prostate cancer: a meta-analysis. Br J Cancer 2001, 85:991-996 